\title{
Regiospecifically Fluorinated Polycyclic Aromatic Hydrocarbons via Julia-Kocienski Olefination and Oxidative Photocyclization. Effect of Fluorine Atom Substitution on Molecular Shape
}

\author{
Shaibal Banerjee ${ }^{\dagger}$, Saikat Sinha ${ }^{\dagger}$, Padmanava Pradhan $^{\dagger}$, Alessio Caruso $\S$, Daniel

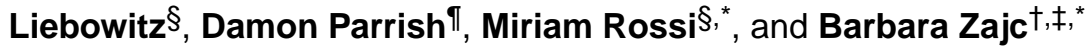 \\ Miriam Rossi: rossi@vassar.edu; Barbara Zajc: bzajc@ccny.cuny.edu \\ tDepartment of Chemistry, The City College of New York, 160 Convent Avenue, New York, New \\ York 10031, United States \\ ¥The Ph.D. Program in Chemistry, The Graduate Center of The City University of New York, New \\ York, New York 10016, United States \\ $\S$ Department of Chemistry, Vassar College, Poughkeepsie, New York 12604, United States \\ INaval Research Laboratory, Code 6030, 4555 Overlook Avenue, Washington D.C. 20375, United \\ States
}

\section{Abstract}

\begin{abstract}
A modular synthesis of regiospecifically fluorinated polycyclic aromatic hydrocarbons (PAHs) is described. 1,2-Diarylfluoroethenes, synthesized via Julia-Kocienski olefination (70-99\% yields), were converted to isomeric 5- and 6-fluorobenzo[c]phenanthrene, 5-and 6-fluorochrysene, and 9and 10-benzo[ $g]$ chrysene (66-83\% yields) by oxidative photocyclization. Photocyclization to 6fluorochrysene proceeded more slowly than conversion of 1-styrylnaphthalene to chrysene. Higher fluoroalkene dilution led to a more rapid cyclization. Therefore, photocyclizations were performed at higher dilutions. To evaluate the effect of fluorine atom on molecular shapes, X-ray data for 5and 6-fluorobenzo[c]phenanthrene, 6-fluorochrysene, 9- and 10-fluorobenzo[ $g]$ chrysene, and unfluorinated chrysene as well as benzo $[g]$ chrysene were obtained and compared. The fluorine atom caused a small deviation from planarity in the chrysene series, decreased nonplanarity in the benzo $[c]$ phenanthrene derivatives, but its influence was most pronounced in the benzo[ $g]$ chrysene series. A remarkable flattening of the molecule was observed in 9-fluorobenzo[ $g]$ chrysene, where the short $2.055 \AA$ interatomic distance between bay-region F-9 and H-8, downfield shift of H-8, and a $26.1 \mathrm{~Hz}$ coupling between F-9 and C-8 indicate a possible F-9 $\cdots$ H-8 hydrogen bond. Also, in 9-fluorobenzo[ $g]$ chrysene, stacking distance is short at $3.365 \AA$ and there is an additional interaction between the $\mathrm{C}-11-\mathrm{H}$ and $\mathrm{C}-10 \mathrm{a}$ of a nearby molecule that is almost perpendicular.
\end{abstract}

\footnotetext{
*Address correspondence to B.Z. Tel: (212) 650-8926, fax: (212) 650-6107; for X-ray related data correspondence to M. R. Tel: (845) 437-5746.

SUPPORTING INFORMATION AVAILABLE

Copies of ${ }^{1} \mathrm{H}$ and ${ }^{13} \mathrm{C}$ NMR spectra, 2D NMR spectra for compounds 4,7 , and 8 , UV spectra of 1-styrylnaphthalene and (E/Z)-1-(2fluoro-2-phenylvinyl)naphthalene, details of the X-ray crystallographic analysis, ORTEP figures and CIF files for compounds 3, 5-8, chrysene, and benzo $[g]$ chrysene.
} 


\section{Graphical Abstract}

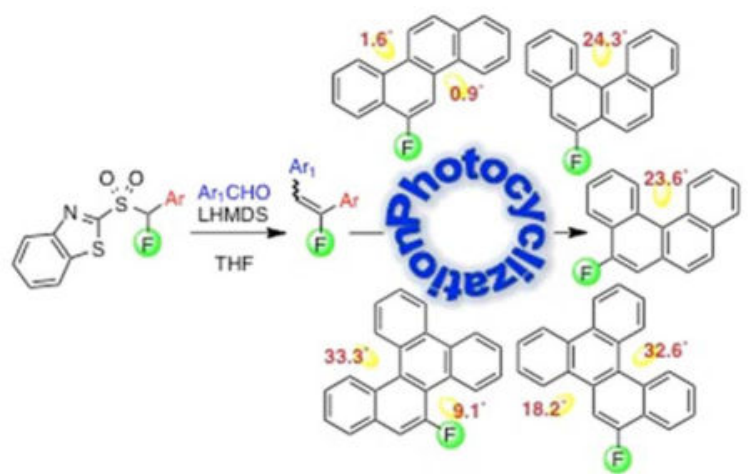

\section{INTRODUCTION}

Fluoroaromatic compounds are of interest in diverse fields, such as materials and supramolecular chemistry, environmental analyses, and biological studies. As examples, applications of fluoroaromatic compounds can be found in liquid crystalline materials, organic light-emitting diodes, and organic field-effect transistors. ${ }^{1,2}$ Recently, polymers containing fluorinated aromatic building blocks have shown improved performance of organic solar cells. ${ }^{2 \mathrm{~d}}$ Use of fluoroaromatics as internal standards in GC-MS analyses has been reported. ${ }^{3}$ In the area of chemical carcinogenesis by polycylic aromatic hydrocarbons (PAHs), ${ }^{4-10}$ fluorinated PAHs have frequently been used in carcinogenicity studies.

Polycyclic aromatic hydrocarbons (PAHs) are the products of activities of modern society and are common contaminants in the environment. ${ }^{4} \mathrm{PAHs}$ that contain a bay or fjord region are known to undergo metabolic activation via a monoxygenase-epoxide hydrolase pathway, where angular-ring diol epoxides are formed. ${ }^{5}$ The electrophilic diol epoxides covalently bind to DNA ultimately resulting in adverse biological effects. ${ }^{6}$ An alternate metabolic pathway involves formation of reactive, redox active $o$-quinones that can lead to DNA damage. ${ }^{7}$ Fluorine is a powerful modulator of biological activity and introduction of fluorine into a PAH is known to significantly alter its biological activity. For example, 6-

fluorobenzo[c]phenanthrene $(6-\mathrm{F}-\mathrm{B} c \mathrm{Ph})$ showed increased tumorigenicity as compared to benzo[c]phenanthrene $(\mathrm{B} c \mathrm{Ph}),{ }^{8}$ whereas 6-fluorobenzo[a]pyrene (6-F-B aP) showed decreased tumorigenicity as compared to benzo[a]pyrene $(\mathrm{BaP}) .{ }^{9}$ In the latter case this is attributed to fluorine-atom-induced conformational change in the metabolite. ${ }^{9 \mathrm{~b}}$ Studies on the effect molecular distortion of PAHs can have on metabolic activation and DNA binding have been conducted using 1,4-difluorobenzo[c]phenanthrene as a model compound. ${ }^{10} \mathrm{In}$ order to better understand the structure-activity relationships on molecular-genetic level, availability of sufficient quantities of regiospecifically fluorinated PAHs is critical.

Our present goal was to explore a convenient, general route to regiospecifically fluorinated PAHs, via the use of fluorinated building blocks, for potential applications in diverse fields. To date, various methods have been used for the introduction of fluorine into polycyclic aromatic systems, such as diazotization-fluorination, ${ }^{11}$ direct electrophilic substitution, ${ }^{12}$ bromine-fluorine exchange, ${ }^{13}$ and cyclizations of smaller fluorinated building blocks. ${ }^{14}$ 
Photocyclizations of stilbene like derivatives with appropriate fluorine atom-substituted and often commercially available aryl moieties are known, ${ }^{10,15}$ and recently

photodehydrofluorination approach to polyfluorinated polycyclic aromatic hydrocarbons has been reported. ${ }^{15 \mathrm{e}}$ Although stilbene can be cyclized readily to phenanthrene, it has been reported that a-fluorostilbene could not be cyclized to the fluoro analogue. ${ }^{15 a}$ Introduction of an additional ring increases the feasibility of photocyclization, and $\beta$-fluoronaphthyl styrene has been converted to 6 -fluorobenzo[c]phenanthrene. ${ }^{11 a}$ Key to this approach was a substrate-dependent regioselective bromofluorination of $\beta$-fluoronaphthyl styrene, followed by elimination, and photochemical closure. On the other hand, synthesis of the isomeric 5fluorobenzo[c]phenanthrene required a completely different approach. ${ }^{11 \mathrm{a}}$ Transition-metalcatalyzed introduction of fluorine atom into aromatics has been the focus of recent research and in the context of PAHs, synthesis of 4-aza-10-fluorophenanthrene, ${ }^{16 a}$ 9-

fluorophenanthrene, ${ }^{16 \mathrm{~b}} 5$-and 6-fluorochrysenes, and fluorinated phenacenes ${ }^{16 \mathrm{c}}$ has been reported. Several fluorinated PAHs (F-PAHs) were synthesized via indium(III)-catalyzed cyclization of aryl- and cyclopentene-substituted 1,1-difluoroallenes, followed by ring expansion and dehydrogenation. ${ }^{17}$ Whereas the latter two methods ${ }^{16 c, 17}$ are mechanistically interesting, one potential limitation is a substrate-dependent formation of isomeric monofluoro PAHs.

We describe herein a general route to a series of regiospecifically fluorinated aryl hydrocarbons. To our knowledge, the use of a fluoro Julia olefination to regiospecifically place a fluorine atom followed by photocyclization has not been studied to date.

\section{RESULTS AND DISCUSSION}

We have been involved with the use of the modified Julia-Kocienski olefination ${ }^{18}$ for novel approaches to variously functionalized regiospecifically fluorinated olefins, ${ }^{19,20}$ including 1,2-diarylfluoroethenes. ${ }^{21}$ Since photodehydrocyclizations of a variety of 1,2-diarylethenes to several classes of PAHs and helicenes have been well documented, ${ }^{22}$ we reasoned that photocyclization of regiospecifically substituted 1,2-diarylfluoroethenes could offer a simple, modular approach to regiospecifically fluorinated PAHs. Importantly, although 1,2diarylfluoroethenes are formed as $E / Z$ mixtures in Julia-Kocienski reactions, the alkene geometry is not critical to the photocyclization, with alkene isomerization occurring under the reaction conditions. Herein, we present a new approach to regiospecifically fluorinated PAHs via a tandem fluoro Julia olefination and oxidative photocyclization. Figure 1 shows a retrosynthetic approach to the modular synthesis of fluorinated PAHs. Also shown in Figure 1 are structures of 5- and 6-fluorobenzo[c]phenanthrene (5-F-B $c \mathrm{Ph}$ and 6-F-B $\mathrm{Ph}), 5-$ and 6fluorochrysene (5-F-Ch and 6-F-Ch), and 9- and 10-fluorobenzo[ $g]$ chrysene (9-F-B $g$ Ch and $10-\mathrm{F}-\mathrm{B} g \mathrm{Ch})$, the targets of our approach.

Previously we have reported high-yield synthesis of regiospecifically fluorinated stilbenelike derivatives via the Julia-Kocienski olefination. ${ }^{21}$ For this, fluorobenzyl heteroaryl sulfones are required. We have previously developed a general synthesis via heterogeneous metalation fluorination of heteroaryl benzyl sulfones and, more specifically the 1,3benzothiazol-2-ylsulfonyl (BT-sulfonyl) derivatives. ${ }^{21}$ For the purpose of this study, fluoro(phenyl)methyl (2a), ${ }^{21}$ fluoro(1-naphthyl)methyl (2b), ${ }^{20 \mathrm{~b}}$ and fluoro(2- 
naphthyl)methyl (2c) ${ }^{21}$ 1,3-benzothiazol-2-yl sulfones were synthesized (Scheme 1), as described. Fluoro(phenanthren-9-yl)methyl 1,3-benzothiazol-2-yl sulfone (2d) was prepared by analogous protocols. ${ }^{20 b, 21}$ Fluorination of sulfones 1a-d using our heterogeneous conditions (LDA, toluene, and addition of solid NFSI) afforded fluorinated sulfone derivatives $\mathbf{2 a - d}$ in high $87-93 \%$ yields. The yields of the critical fluorination step and ${ }^{19} \mathrm{~F}$ NMR data of fluoro sulfones $\mathbf{2 a - d}$ are displayed in Scheme 1.

With sulfone reagents $\mathbf{2 a - d}$, synthesis of regiospecifically fluorinated vinyl compounds was performed via a modified Julia olefination. Condensation of fluorinated BT-sulfones 2a-d with appropriate aldehydes under basic conditions (LHMDS, THF, $0{ }^{\circ} \mathrm{C}$ ) afforded the $E / Z$ monofluoro diarylethylenes (Table 1), the key intermediates for the photocyclization. Initially, photocyclization to 6-F-Ch (3) under Katz conditions, ${ }^{23}$ was performed on a $1 \mathrm{~g}$ scale ( $4.0 \mathrm{mM}$ concentration) of the fluoroalkene (E:Z74\%:26\%), and 6-F-Ch was isolated in $74 \%$ yield. However, the reaction was extremely slow and it took $112 \mathrm{~h}$ to reach completion. Progress of the reaction was monitored by ${ }^{19} \mathrm{~F}$ NMR and is depicted in Figure 2. Upon conducting the photochemical ring closure at a higher dilution $(1 \mathrm{mM})$ of the fluoroalkene, the reaction was complete within $8 \mathrm{~h}$ and 6-F-Ch (3) was isolated in a comparable $72 \%$ yield. Thus, it appears that the overall reaction time is dependent upon substrate concentration, but a longer reaction time does not have a detrimental effect on the yield. In this regard, Katz et al. have shown that in reactions with stoichiometric iodine, a higher substrate concentration led to lower conversion and recovery of starting material, whereas excellent conversion was obtained with increased substrate dilution, in a comparable reaction time. ${ }^{23}$

For comparison, the unfluorinated 1-styrylnaphthalene (E:Z97\%:3\%) was subjected to photocyclization to form chrysene on a $1 \mathrm{~g}$ scale ( $4.38 \mathrm{mM}$ concentration). Progress of the reaction, depicted in Figure 3, was monitored by ${ }^{1} \mathrm{H}$ NMR, by comparing key resonances of the cis- and the trans-alkene, to an aromatic resonance of chrysene at $8.80 \mathrm{ppm}(\mathrm{d}, J=8.3$ $\mathrm{Hz}, 2 \mathrm{H})$. Key resonances of the alkene were the vinylic ${ }^{24} \mathrm{H}\left(=\mathrm{C}-\mathrm{H}_{c i s}: 6.85 \mathrm{ppm}, \mathrm{d}, J=12.4\right.$ $\mathrm{Hz}, 1 \mathrm{H}$; $\left.=\mathrm{C}-\mathrm{H}_{\text {trans: }}: 7.17 \mathrm{ppm}, \mathrm{d}, J=16.1 \mathrm{~Hz}, 1 \mathrm{H}\right)$ and aromatic ${ }^{24} \mathrm{H}(\mathrm{Ar}-\mathrm{H}$ of cis-alkene: $8.09 \mathrm{ppm}$, br d, $J=7.8 \mathrm{~Hz}, 1 \mathrm{H}$; Ar-H of trans-alkene: $8.24 \mathrm{ppm}, \mathrm{d}, J=8.2 \mathrm{~Hz}, 1 \mathrm{H})$. In this case, conversion to chrysene was $97 \%$ complete within $1 \mathrm{~h}$.

UV spectra of the alkene mixtures that were subjected to photocyclization (fluoroalkene $E / Z$ 3:1 and 1-styrylnaphthalene $E: Z \geq 97 \%: 3 \%$ ) were compared, each at $2.3 \times 10^{-5} \mathrm{M}$ concentration. The spectrum of the fluoroalkene mixture shows a hypsochromic shift of both, long- and short-wavelength absorption maxima, as compared to the protio analogue. The long-wavelength absorption of the $E / Z$ fluoroalkenes shows hypochromicity, whereas the short-wavelength absorption shows hyperchromicity as compared to the protio olefins (see the Supporting Information).

Photocyclization to 6-F-Ch in benzene, using a catalytic amount of iodine in air was also attempted on a $0.460 \mathrm{~g}$ scale $(1.85 \mathrm{mM}$ concentration). After 8 hours, analysis of the reaction mixture by ${ }^{19} \mathrm{~F}$ NMR showed resonance corresponding to 6-F-Ch (29\%) and $E / Z$ fluoroalkene resonances (71\%). Further irradiation resulted in consumption of the fluoroalkene after 42 hours, but only a trace of 6-F-Ch was isolated, and other unidentified 
products were formed. Photocyclization to 6-F-Ch in acetone as solvent, under a nitrogen atmosphere, ${ }^{25}$ did not proceed, and the starting material was recovered.

In summary, these results indicated: (a) higher fluoroalkene dilution gave a faster photocyclization, (b) conditions involving catalytic iodine and air were not usable, (c) use of Katz-modified ${ }^{23}$ photocyclization proceeded well, and (d) photocyclization in acetone under nitrogen was ineffective. On the basis of these results, photocyclizations were performed in a Hanovia immersion-type photoreactor using a $450 \mathrm{~W} \mathrm{Hg}$ vapor lamp and a quartz filter. Reactions were conducted in benzene as solvent, with a stoichiometric amount of iodine as the oxidant and propylene oxide as the HI sponge. Under these conditions F-PAHs 4-8 were obtained in $66-83 \%$ yields. Table 1 shows the olefination partners, condensation yields, $E / Z$ olefin ratios, and ${ }^{19} \mathrm{~F}$ NMR data of intermediate fluoroalkenes, as well as the final photocyclization products along with their yields. Notably, ${ }^{19} \mathrm{~F}$ NMR data of PAHs 3-8 (Table 1) showed that the fluorine resonance appears ca. $10 \mathrm{ppm}$ more downfield when it resides in the hydrocarbon bay region (entries 2 and 6), as opposed to when it is not present in a bay region (compare data of PAHs 4 and 8 to those of $3,5,6$, and 7 ).

The final fluorinated products 3-8 were crystallized for analysis by X-ray crystallography. While this work was in progress, independent syntheses and X-ray data for compounds 3 and 4 were published. ${ }^{17}$ In the present work, data analysis of compound $\mathbf{3}$ originates from the crystallographic information we obtained, whereas the analysis of data for compound 4 comes from its published crystallographic data. ${ }^{17}$

In order to gain insight into the influence of the fluorine atom on the shapes of these molecules, angles between the rings of the PAHs were compared to the corresponding unfluorinated PAH (Tables 2-4). Since the X-ray structures of the unfluorinated chrysene $(\mathrm{Ch})$ and benzo $[g]$ chrysene $(\mathrm{B} g \mathrm{Ch})$ were unknown, we also obtained data on these two PAHs (both are commercially available and can also be synthesized via the Julia olefinationphotocyclization approach presented here, using unfluorinated alkenes). Crystallographic structures obtained in this work are shown in Figure 4, and details follow.

In the chrysene series (Table 2$), \mathrm{Ch}$ is completely planar $\left(0^{\circ}\right.$ angle between the four planes), and 6-F-Ch (3) shows a small deviation from planarity, with angles between the planes in the range of $0.4-1.8^{\circ}$. Deviation from planarity for $5-\mathrm{F}-\mathrm{Ch}(4)^{17}$ with a bay-region fluorine atom is larger, with angles between the planes in the range of 1.0-5.9 $9^{\circ}$. The overall distortion from planarity (angle between planes A and D) is $1.8^{\circ}$ for 6-F-Ch (3), and $5.9^{\circ}$ for 5-F-Ch (4).

Although our structure of 6-F-Ch (3) is the same as that published by Fuchibe et al., ${ }^{17}$ our analysis of its crystal structure differed in the treatment of the hydrogen atom fluorine atom positions. All hydrogen atom positions were found and refined from our X-ray data, whereas Fuchibe et al. ${ }^{17}$ calculated the idealized hydrogen atom positions. That fluorine exhibits positional disorder is well-established, ${ }^{26}$ and indeed, for 6-F-Ch (3) the fluorine atom occurs $78 \%$ of the time at the C- 6 (major occupancy position) and $22 \%$ of the time at the C-12 position. The remainder of the time, at these positions, fluorine is replaced by a hydrogen atom. The C-F bond length of the major occupancy fluorine is 1.343(3) $\AA$ while the C-F bond for the minor occupancy fluorine, as expected, is in between a $\mathrm{C}-\mathrm{H}$ and $\mathrm{C}-\mathrm{F}$ bond 
length, 1.146(9) ^. From our experimentally determined hydrogen atom positions, we can see two dominant intermolecular interactions, a strong stacking interaction and a $\mathrm{C}-8-\mathrm{H} \cdots \mathrm{F}$ interaction (Figure 5). The stacking interaction of 3.421(5) $\AA$ is between the planes of 6-F$\mathrm{Ch}(\mathbf{3})$ molecules. The second interaction is the hydrogen bond between the major occupancy F (at C-6) and the H-8-C-8 of a neighboring molecule at 2.516(9) $\AA$ that is perpetuated throughout the crystal structure. This $\mathrm{C}-\mathrm{H} \cdots \mathrm{F}$ distance is shorter than the calculated distance of $2.619 \AA$ from the published crystal structure having calculated hydrogen atom positions of C-6-F...H-8. We also see additional intermolecular interactions between $\mathrm{C}-\mathrm{H}$ and ring carbon atoms of $2.844 \AA$, $2.895 \AA$, and $2.889 \AA$. These are approximately perpendicular (Figure 5).

In $\mathrm{B} c \mathrm{Ph}$ series, the overall distortion from planarity in $5-\mathrm{F}-\mathrm{B} c \mathrm{Ph}(\mathbf{5})$ and in 6-F- $\mathrm{B} c \mathrm{Ph}(\mathbf{6})$ is smaller than in the parent hydrocarbon (Table 3 and Figure 4). This is reflected in the angle between rings $\mathrm{A}$ and $\mathrm{D}$ forming the fjord region and in the angle between rings $\mathrm{A}$ and $\mathrm{C}$. The angle between rings $\mathrm{A}$ and $\mathrm{D}$ is $26.7^{\circ}$ in $\mathrm{BcPh}$, and decreases to $24.3^{\circ}$ and $23.6^{\circ}$ in 6-F$\mathrm{B} c \mathrm{Ph}(\mathbf{6})$ and 5-F- $\mathrm{B} c \mathrm{Ph}(5)$, respectively. The angle between rings $\mathrm{A}$ and $\mathrm{C}$ is $18.1^{\circ} \mathrm{in} \mathrm{B} c \mathrm{Ph}$, $16.2^{\circ}$ in $6-\mathrm{F}-\mathrm{B} c \mathrm{Ph}(\mathbf{6})$, and $14.2^{\circ}$ in $5-\mathrm{F}-\mathrm{B} c \mathrm{Ph}(\mathbf{5})$.

The most pronounced effect fluorine atom has on the molecular shape is in the benzo $[g]$ chrysene series. Here again, the overall distortion from planarity decreases upon fluorine atom substitution (Table 4 and Figure 4). The angle between rings $\mathrm{A}$ and $\mathrm{D}$ forming the fjord region is $36.0^{\circ}$ in the parent $\mathrm{BgCh}$, and this decreases to $32.6^{\circ}$ in $10-\mathrm{F}-\mathrm{B} g \mathrm{Ch}(7)$ and to $33.3^{\circ}$ in $9-\mathrm{F}-\mathrm{B} g \mathrm{Ch}(\mathbf{8})$. However, the angles between rings $\mathrm{B}$ and $\mathrm{E}$, which form a bay region, show the most remarkable difference. The angle between rings $\mathrm{B}$ and $\mathrm{E}$ is $20.1^{\circ}$ in the parent hydrocarbon, decreasing to $18.2^{\circ}$ in $10-\mathrm{F}-\mathrm{B} g \mathrm{Ch}(7)$, and this decreases dramatically to $9.2^{\circ}$ in $9-\mathrm{F}-\mathrm{B} g \mathrm{Ch}(\mathbf{8})$. In 9-F-B $g \mathrm{Ch}(\mathbf{8})$, the fluorine atom resides in the bay region, and the interatomic distance between F-9 and the bay-region $\mathrm{H}-8$ is $2.055 \AA$, with a $\mathrm{C}-\mathrm{H} \cdots \mathrm{F}$ angle of $128.73^{\circ}$, which suggests a possible hydrogen bond. ${ }^{27,28}$ In the ${ }^{1} \mathrm{H}$ NMR spectrum of 9-F-B $g \mathrm{Ch}(\mathbf{8}), \mathrm{H}-8$ appears at $9.07 \mathrm{ppm}$, and is shifted downfield as compared to $\mathrm{H}-8$ in unsubstituted $\mathrm{B} g \mathrm{Ch}$, where it appears at $8.63 \mathrm{ppm} .{ }^{29}$ The bay-region $\mathrm{H}-8$ and F-9 resonances in compound 8 show a small $\sim 2 \mathrm{~Hz}$ coupling ( 2.3 and $2.2 \mathrm{~Hz}$, respectively). In the ${ }^{13} \mathrm{C}$ NMR spectrum of 9-F-B $g \mathrm{Ch}(\mathbf{8})$, the $\mathrm{C}-8$ resonance appears at $128.0 \mathrm{ppm}$, as a doublet with a $J=26.1 \mathrm{~Hz}$. This is a typical value for a scalar two-bond C-F coupling constant. The downfield shift of the H-8 proton, its coupling to F-9, and the large C-8-F coupling constant further support possible hydrogen bonding between F-9 and H-8. ${ }^{27,28}$ It is plausible, therefore, that the tendency towards $\mathrm{F}-\mathrm{H}$ bonding is responsible for the planarization in B-, C-, E-ring region, decreasing the angles between these rings in 9-F$\mathrm{B} g \mathrm{Ch}(\mathbf{8})$. The hydrogen atom positions in the 9-F-BgCh structure were calculated.

Additional strong intermolecular interactions include the short stacking distance at $3.365 \AA$ and two additional short almost perpendicular interactions: one at $2.875 \AA$ between the $\mathrm{C}-11-\mathrm{H}$ and $\mathrm{C}-10$ a of a nearby molecule and another at 2.872 between $\mathrm{C}-4-\mathrm{H}$ and $\mathrm{C}-6$ of a neighboring molecule (Figure 6).

In 5-F-Ch (4), which also has a fluorine atom residing in the bay region, the interatomic distance between F-5 and the bay-region H-4 is $2.069 \AA$, with a C-H $\cdots \mathrm{F}$ angle of $126.80^{\circ}$, again suggestive of intramolecular hydrogen bonding. The ${ }^{1} \mathrm{H}$ and ${ }^{13} \mathrm{C}$ NMR spectra of 5-F- 
$\mathrm{Ch}$ (4) show similar features to those of 9-F-B $g \mathrm{Ch}(\mathbf{8})$. In the ${ }^{1} \mathrm{H}$ NMR spectrum of 5-F-Ch (4), the bay-region $\mathrm{H}-4$ appears at $9.25 \mathrm{ppm}$, and is downfield shifted as compared to H-4 in unsubstituted chrysene $(\mathrm{Ch})$, which appears at $8.79 \mathrm{ppm}^{30}$ The bay-region H-4 and F-5 resonances in compound 4 show a $\sim 3 \mathrm{~Hz}$ coupling $\left(2.8\right.$ and $3.3 \mathrm{~Hz}$, respectively). In the ${ }^{13} \mathrm{C}$ NMR spectrum of 5-F-Ch (4), the bay-region C-4 appears at $128.0 \mathrm{ppm}$, as a doublet, with a large $26.6 \mathrm{~Hz}$ coupling constant with the fluorine atom.

Through-space spin-spin coupling has been a subject of research for several years now. ${ }^{31} \mathrm{In}$ previous studies, other investigators have reported comparable NMR spectral features for PAHs containing a bay-region fluorine atom. Mallory et al. suggested through-space H-F coupling interactions in 4-fluorophenanthrene, where a $2.6 \mathrm{~Hz} \mathrm{H}-\mathrm{F}$ coupling was observed between the bay-region fluorine atom and the bay-region H-5. ${ }^{32}$ In the present case, resonances of bay-region H-8 and F-9 of compound 8 show a similar small $\sim 2 \mathrm{~Hz}$ coupling, whereas resonances of bay-region H-4 and F-5 of compound 4 show a $\sim 3 \mathrm{~Hz}$ coupling. Sardella et al. studied ${ }^{1} \mathrm{H}$ and ${ }^{13} \mathrm{C}$ NMR spectra of PAHs containing a bay-region fluorine atom. ${ }^{33}$ Similar to what we have observed for compounds $\mathbf{8}$ and $\mathbf{4}$, a C-F coupling of 24.9 $\mathrm{Hz}$ across the bay region was reported, and through-space $\mathrm{C}-\mathrm{F}$ coupling interactions were suggested. ${ }^{33}$

We also obtained ${ }^{1} \mathrm{H}-{ }^{19} \mathrm{~F}$ HOESY spectra of 9-F-BgCh $(\mathbf{8}$, left, Figure 7) and 5-F-Ch (4, right, Figure 7). The HOESY spectrum of $9-\mathrm{F}-\mathrm{B} g \mathrm{Ch}(\mathbf{8})$ shows an intense interaction between the fluorine atom and the $\mathrm{H}-8$ resonance at $9.07 \mathrm{ppm}$, in support of $\mathrm{C}-8-\mathrm{H} \cdots \mathrm{F}$ hydrogen bonding. The weaker interaction is between the fluorine atom and the H-10 resonance at $7.67 \mathrm{ppm}$. The HOESY spectrum of 5-F-Ch (4) shows an intense interaction between the fluorine atom and the $\mathrm{H}-4$ resonance at $9.25 \mathrm{ppm}$, in support of $\mathrm{C}-4-\mathrm{H} \cdots \mathrm{F}$ hydrogen bonding. The weaker interaction is between the fluorine atom and the H-6 resonance at $7.68 \mathrm{ppm}$.

\section{CONCLUSIONS}

1,2-Diarylfluoroethenes, which were synthesized via Julia-Kocienski olefination, were subjected to oxidative photocyclization to yield regiospecifically substituted monofluoro PAHs. Photocyclizations of the 1,2-diarylfluoroethenes were much slower as compared to those of their unfluorinated analogues, and higher dilutions produced faster reactions. The method is straighforward, highly modular, and is applicable to the synthesis of fluoro PAHs and potentially to other fluoro PAHs that contain additionally substituted aryl moieties.

It has recently been reported that introduction of fluorine atom into phenacenes does not change their shape. ${ }^{16 \mathrm{c}}$ However, in the present cases, we have observed that fluorine-atom substitution does elicit influence on the shapes of the molecules when compared to their unfluorinated analogues. A small deviation from planarity was observed for 6-F-Ch in comparison to chrysene, which is planar, and deviation from planarity increased in 5-F-Ch containing a bay-region fluorine atom. On the other hand, in comparison to $\mathrm{Bch}$, both 5and 6-F-B $\mathrm{Ph}$ are slightly less nonplanar. Also, as reported by other investigators, we have observed positional disorder in the fluorine atom positions. Additionally, the molecular assemblies in the crystal structure are stabilized by $\pi-\pi$ stacking interactions as well as 
through the formation of $\mathrm{C}-\mathrm{H} \cdots \mathrm{F}$ intermolecular interactions. These features highlight the important role that fluorine substitution plays in organic molecules. Earlier studies by Thalladi et al. ${ }^{34}$ showed that, in general, $\mathrm{C}-\mathrm{H} \cdots \mathrm{F}$ hydrogen bonds were preferred to $\mathrm{F} \cdots \mathrm{F}$ contacts. The marked difference in crystal packing behavior between fluorine and the heavier halogens is confirmed with our molecules. In more angularly fused $\mathrm{B} g \mathrm{Ch}$ series, a more dramatic shape change occurred, with the most pronounced effect in 9-F-B $g \mathrm{Ch}$. In this case, the fluorine atom resides in the bay region and causes substantial planarization of $\mathrm{B}, \mathrm{C}$, E rings forming the bay region, possibly via intramolecular F...H bonding.

\section{EXPERIMENTAL SECTION}

THF was distilled over $\mathrm{LiAlH}_{4}$ and then over sodium, toluene and benzene were distilled over sodium, and $\mathrm{CH}_{2} \mathrm{Cl}_{2}$ was distilled over $\mathrm{CaCl}_{2}$. DMF was obtained from commercial sources and was used without further purification. For reactions performed in a nitrogen atmosphere, glassware was dried with heat gun under vacuum. LDA (2.0 M solution in heptane/THF/EtPh) and LHMDS (1.0 M in THF) were obtained from commercial sources. All other reagents were obtained from commercial sources and were used as received. We have previously reported syntheses of 2-[fluoro(phenyl)methylsulfonyl]benzo[ $d$ ] thiazole (2a), ${ }^{21}$ 2-[fluoro(naphthalen-1-yl)methylsulfonyl]benzo[ $d$ ] thiazole (2b), ${ }^{20 b}$ and of 2[fluoro(naphthalen-2-yl)methylsulfonyl]benzo[d]thiazole $(\mathbf{2 c}),{ }^{21}$ and their precursor sulfones $\mathbf{1 a},{ }^{21} \mathbf{1 b},{ }^{20 b}$ and $\mathbf{1 c} \cdot{ }^{21}$ Photocyclizations of alkenes were performed in a Hanovia immersion-type photoreactor using a $450 \mathrm{~W} \mathrm{Hg}$ vapor lamp and a quartz filter. Thin layer chromatography was performed on glass-backed silica gel plates $(250 \mu \mathrm{m})$. Column chromatographic purifications were performed on 200-300 mesh silica gel. ${ }^{1} \mathrm{H}$ NMR spectra were recorded at $500 \mathrm{MHz}$ and were referenced to residual protio solvent. ${ }^{13} \mathrm{C}$ NMR spectra were recorded at $125 \mathrm{MHz}$ and were referenced to the carbon resonance of the deuterated solvent. ${ }^{19} \mathrm{~F}$ NMR spectra were recorded at $282 \mathrm{MHz}$ with $\mathrm{CFCl}_{3}$ as the internal standard. Chemical shifts $(\delta)$ are reported in parts per million, and coupling constants $(J)$ are in hertz $(\mathrm{Hz})$. On the basis of 2D NMR data, some proton and carbon assignments were made for 5fluorochrysene (4), 10-fluorobenzo[ $g]$ chrysene (7), and 9-fluorobenzo[ $g]$ chrysene (8). HRMS data were obtained using a FTICR-MS, the ionization modes are specified under each compound heading.

\section{Synthesis of 2-\{[Fluoro(phenanthren-9-yl)methyl]sulfonyl\}benzo[d]thiazole 2d}

2-[(Phenanthren-9-ylmethyl)thio]benzo[d]thiazole-To a solution of the sodium salt of 1,3-benzo-2-thiazole (1.324 g, $7.00 \mathrm{mmol}, 1.25$ molar equiv) in DMF (20 mL) was added a solution of 9-(bromomethyl)phenanthrene $(1.518 \mathrm{~g}, 5.60 \mathrm{mmol})$ in DMF $(30 \mathrm{~mL})$. The mixture was stirred at rt and monitored by $\mathrm{TLC}\left(\mathrm{SiO}_{2}, 20 \%\right.$ EtOAc in hexanes). After $6.0 \mathrm{~h}$, complete consumption of 9-(bromomethyl)phenanthrene was observed, and the reaction was quenched with aq $\mathrm{NH}_{4} \mathrm{Cl}$ solution $(30 \mathrm{~mL})$. The mixture was extracted with EtOAc (3x), the combined organic layers were washed aq $\mathrm{NaHCO}_{3}$ solution $(30 \mathrm{~mL})$, brine $(30 \mathrm{~mL})$, and dried over anhydrous $\mathrm{Na}_{2} \mathrm{SO}_{4}$. The organic layer was concentrated under reduced pressure, and crude product was purified by column chromatography $\left(\mathrm{SiO}_{2}, 10 \%\right.$ EtOAc in hexanes) to yield pure 2-[(phenanthren-9-ylmethyl)thio]benzo[ $d$ ] thiazole $(1.821 \mathrm{~g}, 91 \%)$ as a colorless solid. ${ }^{1} \mathrm{H}$ NMR $\left(500 \mathrm{MHz}, \mathrm{CDCl}_{3}\right): \delta 8.76(\mathrm{br} \mathrm{dd}, J=8.5,1.4 \mathrm{~Hz}, 1 \mathrm{H}), 8.67(\mathrm{~d}, J=$ 
$8.3 \mathrm{~Hz}, 1 \mathrm{H}), 8.22$ (br dd, $J=8.3,1.9 \mathrm{~Hz}, 1 \mathrm{H}), 7.98$ (d, $J=8.3 \mathrm{~Hz}, 1 \mathrm{H}), 7.94$ (s, 1H), 7.86 (d, $J=7.4 \mathrm{~Hz}, 1 \mathrm{H}), 7.77(\mathrm{~d}, J=8.3 \mathrm{~Hz}, 1 \mathrm{H}), 7.72-7.64(\mathrm{~m}, 3 \mathrm{H}), 7.59(\mathrm{td}, J=7.4,0.9 \mathrm{~Hz}, 1 \mathrm{H})$, $7.47(\mathrm{td}, J=7.7,1.2 \mathrm{~Hz}, 1 \mathrm{H}), 7.33(\mathrm{td}, J=7.8,0.9 \mathrm{~Hz}, 1 \mathrm{H}), 5.18(\mathrm{~s}, 2 \mathrm{H}) .{ }^{13} \mathrm{C}$ NMR $(125$ $\left.\mathrm{MHz}, \mathrm{CDCl}_{3}\right): \delta 166.7,153.4,135.6,131.5,131.1,130.8,130.5,130.0,129.4,128.8,127.3$, 127.2, 127.1, 127.0, 126.3, 124.63, 124.55, 123.6, 122.8, 121.8, 121.3, 36.4. HRMS (ESI) $[\mathrm{M}+\mathrm{H}]^{+}$calcd. for $\mathrm{C}_{22} \mathrm{H}_{16} \mathrm{NS}_{2} 358.0719$, found 358.0723.

2-[(Phenanthren-9-ylmethyl)sulfonyl]benzo[d]thiazole 1d-A solution of 2[(phenanthren-9-ylmethyl)thio]benzo[d]thiazole (0.943 g, $2.64 \mathrm{mmol})$ in $\mathrm{CH}_{2} \mathrm{Cl}_{2}(40 \mathrm{~mL})$ was added dropwise to a solution of $m \mathrm{CPBA}(1.365 \mathrm{~g}, 7.91 \mathrm{mmol}, 3.00$ molar equiv) in $\mathrm{CH}_{2} \mathrm{Cl}_{2}(30 \mathrm{~mL})$, cooled to $0{ }^{\circ} \mathrm{C}$. After complete addition, the mixture was stirred at $\mathrm{rt}$ overnight. The reaction was quenched with aq $\mathrm{NaHCO}_{3}(30 \mathrm{~mL})$, the organic layer was separated and washed with aq $\mathrm{NaHCO}_{3}(30 \mathrm{~mL}), 5 \%$ aq $\mathrm{NaOH}(30 \mathrm{~mL}$, twice), water and then brine $\left(30 \mathrm{~mL}\right.$ each), and dried over anhydrous $\mathrm{Na}_{2} \mathrm{SO}_{4}$. The solvent was removed under reduced pressure, and crude product was purified by column chromatography $\left(\mathrm{SiO}_{2}, 30 \%\right.$ EtOAc in hexanes) to yield pure 2-[(phenanthren-9-ylmethyl)sulfonyl]benzo[ $d]$ thiazole (1d) as a colorless solid $(0.728 \mathrm{~g}, 71 \%) .{ }^{1} \mathrm{H} \mathrm{NMR}\left(500 \mathrm{MHz}, \mathrm{CDCl}_{3}\right): \delta 8.68(\mathrm{~d}, J=8.3 \mathrm{~Hz}, 1 \mathrm{H})$, $8.64(\mathrm{~d}, J=8.3 \mathrm{~Hz}, 1 \mathrm{H}), 8.29(\mathrm{~d}, J=8.3 \mathrm{~Hz}, 1 \mathrm{H}), 8.11(\mathrm{~d}, J=8.3 \mathrm{~Hz}, 1 \mathrm{H}), 7.86(\mathrm{~d}, J=8.3$ $\mathrm{Hz}, 1 \mathrm{H}), 7.75$ (s, 1H), 7.72 (d, $J=7.8 \mathrm{~Hz}, 1 \mathrm{H}), 7.69-7.64(\mathrm{~m}, 2 \mathrm{H}), 7.61$ (t, $J=7.6 \mathrm{~Hz}, 1 \mathrm{H})$, 7.57-7.51 (m, 3H), $5.32(\mathrm{~s}, 2 \mathrm{H}) .{ }^{13} \mathrm{C}$ NMR $\left(125 \mathrm{MHz}, \mathrm{CDCl}_{3}\right): \delta 165.6,152.8,137.4,133.0$, 131.05, 130.98, 130.92, 130.5, 129.0, 128.2, 128.0, 127.8, 127.14, 127.12, 127.0, 125.6, 124.6, 123.3, 122.7, 122.4, 121.6, 58.7. HRMS (ESI) $[\mathrm{M}+\mathrm{H}]^{+}$calcd. for $\mathrm{C}_{22} \mathrm{H}_{16} \mathrm{NO}_{2} \mathrm{~S}_{2}$ 390.0617 , found 390.0622 .

2-\{[Fluoro(phenanthren-9-yl)methyl]sulfonyl\}benzo[d]thiazole 2d-A stirring solution of sulfone $1 \mathbf{d}(0.488 \mathrm{~g}, 1.25 \mathrm{mmol})$ in dry toluene $(80 \mathrm{~mL})$ was cooled under nitrogen gas to $-78{ }^{\circ} \mathrm{C}$ (dry ice/iPrOH). LDA ( $0.800 \mathrm{~mL}, 1.60 \mathrm{mmol}, 1.28$ molar equiv) was added, and after $12 \mathrm{~min}$, solid NFSI ( $0.488 \mathrm{~g}, 1.55 \mathrm{mmol}, 1.24$ molar equiv) was added. The reaction mixture was allowed to stir at $-78{ }^{\circ} \mathrm{C}$ for $50 \mathrm{~min}$, then warmed to rt, and stirring was continued for an additional $50 \mathrm{~min}$. Saturated aq $\mathrm{NH}_{4} \mathrm{Cl}$ was added to the reaction mixture, and the layers were separated. The aqueous layer was extracted with EtOAc (3x), and the combined organic layer was washed with saturated aq $\mathrm{NaHCO}_{3}(30 \mathrm{~mL})$ and brine $(30 \mathrm{~mL})$. The organic layer was dried over anhydrous $\mathrm{Na}_{2} \mathrm{SO}_{4}$, and the solvent was evaporated under reduced pressure. The crude product was purified by column chromatography $\left(\mathrm{SiO}_{2}, 20 \%\right.$ EtOAc in hexanes) to yield pure 2-\{[fluoro(phenanthren-9yl)methyl]sulfonyl \}benzo[ $d$ ]thiazole $2 \mathbf{d}$ as a white solid $(0.357 \mathrm{~g}, 70 \%)$. ${ }^{1} \mathrm{H}$ NMR (500 $\left.\mathrm{MHz}, \mathrm{CDCl}_{3}\right): \delta 8.76-8.73(\mathrm{~m}, 1 \mathrm{H}), 8.68(\mathrm{~d}, J=8.3 \mathrm{~Hz}, 1 \mathrm{H}), 8.34-8.32(\mathrm{~m}, 2 \mathrm{H}), 8.21(\mathrm{~s}$, $1 \mathrm{H}), 8.02(\mathrm{~d}, J=8.3 \mathrm{~Hz}, 1 \mathrm{H}), 7.94(\mathrm{~d}, J=7.8 \mathrm{~Hz}, 1 \mathrm{H}), 7.76-7.60(\mathrm{~m}, 6 \mathrm{H}), 7.54(\mathrm{~d}, J=45.1$ $\mathrm{Hz}, 1 \mathrm{H}) .{ }^{13} \mathrm{C} \mathrm{NMR}\left(125 \mathrm{MHz}, \mathrm{CDCl}_{3}\right): \delta 163.5,153.1,137.7,131.8$, three resonances at 131.0, 130.9, 130.8 (2C, one s and one d), 130.4, 129.9, 129.1 (d, $J=6.5 \mathrm{~Hz}), 128.9,128.6$, 128.0, 127.6, 127.4 (2C), 125.9, 124.3, 123.5, 122.8, 122.5, 121.3 (d, $J=17.3 \mathrm{~Hz}), 99.8$ (d, $J$ $=221.9 \mathrm{~Hz}) .{ }^{19} \mathrm{~F}$ NMR $\left(282 \mathrm{MHz}, \mathrm{CDCl}_{3}\right): \delta-171.5$ (d, $\left.J=42.7 \mathrm{~Hz}\right)$. HRMS (ESI) [M $+\mathrm{Na}]^{+}$calcd. for $\mathrm{C}_{22} \mathrm{H}_{14} \mathrm{FNO}_{2} \mathrm{~S}_{2} \mathrm{Na} 430.0342$, found 430.0339 . 


\section{Synthesis of 6-Fluorochrysene $3^{12 a, 16 c, 17,35}$}

Step 1. Condensation of 2a with 1-naphthaldehyde-A solution of 1naphthaldehyde $(0.491 \mathrm{~g}, 3.14 \mathrm{mmol})$ and sulfone $2 \mathrm{a}(1.161 \mathrm{~g}, 3.59 \mathrm{mmol}, 1.14$ molar equiv) in dry THF $(60 \mathrm{~mL})$ was cooled to $0{ }^{\circ} \mathrm{C}$ under a nitrogen atmosphere. LHMDS (7.60 $\mathrm{mL}, 7.60 \mathrm{mmol}, 2.42$ molar equiv) was added dropwise at $0{ }^{\circ} \mathrm{C}$. The mixture was stirred at $0{ }^{\circ} \mathrm{C}$ for $10 \mathrm{~min}$, allowed to warm to rt and stirred at rt. After $1 \mathrm{~h}$, TLC $(10 \%$ EtOAc in hexanes) showed complete disappearance of the aldehyde. Saturated aq $\mathrm{NH}_{4} \mathrm{Cl}(30 \mathrm{~mL})$ was added and the mixture was extracted with EtOAc (3x). The combined organic layer was washed with $\mathrm{NaHCO}_{3}(30 \mathrm{~mL})$, brine $(30 \mathrm{~mL})$, and then dried over anhydrous $\mathrm{Na}_{2} \mathrm{SO}_{4}$. The solvent was evaporated under reduced pressure and the crude product was purified by column chromatography $\left(\mathrm{SiO}_{2}\right.$, eluted with hexanes, followed by $2 \%$ EtOAc in hexanes) to yield pure (E/Z)-1-(2-fluoro-2-phenylvinyl)naphthalene ( $E: Z$ ratio 2.8:1) as a colorless liquid $(0.773 \mathrm{~g}, 99 \%) .{ }^{19} \mathrm{~F} \mathrm{NMR}\left(282 \mathrm{MHz}, \mathrm{CDCl}_{3}\right): \delta-100.0(\mathrm{~d}, J=21.4 \mathrm{~Hz}, 1 \mathrm{~F}),-115.6$ (d, $J=39.7 \mathrm{~Hz}, 1 \mathrm{~F}$ ). HRMS (+APPI mode) $[\mathrm{M}]^{+}$calcd. for $\mathrm{C}_{18} \mathrm{H}_{13} \mathrm{~F} 248.0996$, found 248.0997 .

\section{Step 2. Photocyclization of (E/Z)-1-(2-fluoro-2-phenylvinyl)naphthalene to} 3. ${ }^{12 a, 16 c, 17,35}$-(E/Z)-1-(2-fluoro-2-phenylvinyl)naphthalene (E:Z ratio 2.8:1, 63.1 mg, $0.254 \mathrm{mmol})$ was dissolved in benzene $(250 \mathrm{~mL}), \mathrm{I}_{2}(71.1 \mathrm{mg}, 0.280 \mathrm{mmol}, 1.10 \mathrm{molar}$ equiv) was added, and nitrogen was bubbled into the solution for $10 \mathrm{~min}$. Propylene oxide (2.90 mL, $2.41 \mathrm{~g}, 41.4 \mathrm{mmol}, 163$ molar equiv) was added, the solution was subjected to irradiation, and the reaction was monitored by ${ }^{19} \mathrm{~F}$ NMR. After $8 \mathrm{~h},{ }^{19} \mathrm{~F}$ NMR showed consumption of the $(E / Z)$-alkene. The solvent was evaporated and the crude product was purified by column chromatography $\left(\mathrm{SiO}_{2}, 2 \%\right.$ EtOAc in hexanes) to afford pure 6fluorochrysene 3 (45.1 mg, 72\%) as a white solid. For X-ray analysis, this compound was crystallized from hexanes/2-3 drops of $\mathrm{CH}_{2} \mathrm{Cl}_{2} .{ }^{1} \mathrm{H}$ NMR (500 MHz, $\mathrm{CDCl}_{3}$ ): $\delta 8.79$ (d, $J=$ $8.3 \mathrm{~Hz}, 1 \mathrm{H}), 8.66(\mathrm{~d}, J=9.2 \mathrm{~Hz}, 1 \mathrm{H}), 8.63(\mathrm{~d}, J=8.3 \mathrm{~Hz}, 1 \mathrm{H}), 8.35$ (d, $J=12.9 \mathrm{~Hz}, 1 \mathrm{H})$, $8.29(\mathrm{~d}, J=7.8 \mathrm{~Hz}, 1 \mathrm{H}), 8.00(\mathrm{~d}, J=8.3 \mathrm{~Hz}, 1 \mathrm{H}), 7.98(\mathrm{~d}, J=9.2 \mathrm{~Hz}, 1 \mathrm{H}), 7.79(\mathrm{t}, J=7.6$ $\mathrm{Hz}, 1 \mathrm{H}), 7.72$ (t, $J=7.6 \mathrm{~Hz}, 2 \mathrm{H}), 7.66$ (t, $J=7.4 \mathrm{~Hz}, 1 \mathrm{H}) .{ }^{13} \mathrm{C} \mathrm{NMR}\left(125 \mathrm{MHz}, \mathrm{CDCl}_{3}\right): \delta$ 158.1 (d, $J=250.8 \mathrm{~Hz}$ ), 132.6, 132.2 (d, $J=5.8 \mathrm{~Hz}$ ), 130.4 (d, $J=4.4 \mathrm{~Hz}$ ), 128.9 (one resonance of the doublet partially buried under a singlet), 128.8, 127.9, 127.0, 126.9, 126.7 (d, $J=2.2 \mathrm{~Hz}), 125.5,123.9$ (d, $J=17.8 \mathrm{~Hz}), 123.5(\mathrm{~d}, J=3.2 \mathrm{~Hz}), 123.4,121.4(\mathrm{~d}, J=5.9$ $\mathrm{Hz}), 121.1,104.1(\mathrm{~d}, J=22.0 \mathrm{~Hz}) .{ }^{19} \mathrm{~F} \mathrm{NMR}\left(282 \mathrm{MHz}, \mathrm{CDCl}_{3}\right): \delta-123.8(\mathrm{~d}, J=15.3 \mathrm{~Hz})$.

\section{Synthesis of 5-Fluorochrysene $4^{16 c, 17}$}

Step 1. Condensation of $\mathbf{2} \mathbf{b}$ with benzaldehyde-A solution of benzaldehyde (38.8 $\mathrm{mg}, 0.366 \mathrm{mmol}$ ) and sulfone $\mathbf{2 b}$ ( $147 \mathrm{mg}, 0.411 \mathrm{mmol}, 1.12$ molar equiv) in dry THF (20 $\mathrm{mL}$ ) was cooled to $0{ }^{\circ} \mathrm{C}$ under a nitrogen atmosphere. LHMDS $(0.980 \mathrm{~mL}, 0.980 \mathrm{mmol}$, 2.68 molar equiv) was added dropwise at $0{ }^{\circ} \mathrm{C}$. The mixture was stirred at $0{ }^{\circ} \mathrm{C}$ for $10 \mathrm{~min}$, allowed to warm to rt and stirred at rt. After $1 \mathrm{~h}, \mathrm{TLC}$ (5\% EtOAc in hexanes) showed complete disappearance of the aldehyde. Saturated aq $\mathrm{NH}_{4} \mathrm{Cl}(30 \mathrm{~mL})$ was added and the mixture was extracted with EtOAc (3x). The combined organic layer was washed with $\mathrm{NaHCO}_{3}(30 \mathrm{~mL})$, brine $(30 \mathrm{~mL})$, and then dried over anhydrous $\mathrm{Na}_{2} \mathrm{SO}_{4}$. The solvent was evaporated under reduced pressure and the crude product was purified by column chromatography ( $\mathrm{SiO}_{2}$, eluted with 5\% EtOAc in hexanes) to yield pure (E/Z)-1-(1-fluoro-2- 
phenylvinyl)naphthalene $(E: Z$ ratio $2.9: 1,73.5 \mathrm{mg}, 81 \%) .{ }^{19} \mathrm{~F}$ NMR $\left(282 \mathrm{MHz}, \mathrm{CDCl}_{3}\right): \delta$ $-84.4(\mathrm{~d}, J=18.3 \mathrm{~Hz}, 1 \mathrm{~F}),-95.2(\mathrm{~d}, J=39.7 \mathrm{~Hz}, 1 \mathrm{~F})$. HRMS (+APPI mode) $[\mathrm{M}]^{+}$calcd. for $\mathrm{C}_{18} \mathrm{H}_{13} \mathrm{~F} 248.0996$, found 248.1000 .

Step 2. Photocyclization of (E/Z)-1-(1-fluoro-2-phenylvinyl)naphthalene to 4. ${ }^{16 c, 17}$-(E/Z)-1-(1-Fluoro-2-phenylvinyl)naphthalene ( $E: Z$ ratio $2.9: 1,70.0 \mathrm{mg}, 0.282$ mmol) was dissolved in benzene $(250 \mathrm{~mL}), \mathrm{I}_{2}(78.3 \mathrm{mg}, 0.308 \mathrm{mmol}, 1.10$ molar equiv) was added, and nitrogen was bubbled into the solution for $10 \mathrm{~min}$. Propylene oxide $(3.20 \mathrm{~mL}$, $2.66 \mathrm{~g}, 45.8 \mathrm{mmol}, 162$ molar equiv) was added, the solution was subjected to irradiation, and the reaction was monitored by ${ }^{19} \mathrm{~F}$ NMR. After $16 \mathrm{~h},{ }^{19} \mathrm{~F}$ NMR showed consumption of the alkene. The solvent was evaporated and the crude product was purified by column chromatography $\left(\mathrm{SiO}_{2}, 2 \% \mathrm{CH}_{2} \mathrm{Cl}_{2}\right.$ in hexanes) to yield pure 5-fluorochrysene $\mathbf{4}$ as a white solid (49.2 mg, 71\%). For X-ray analysis, this compound was crystallized from hexanes/2-3 drops of $\mathrm{CH}_{2} \mathrm{Cl}_{2} .{ }^{1} \mathrm{H}$ NMR (500 MHz, $\mathrm{CDCl}_{3}$ ): $\delta 9.25$ (dd, $\left.J=8.3,2.8 \mathrm{~Hz}, 1 \mathrm{H}, \mathrm{H}-4\right), 8.75$ (dd, $J=7.8,0.9 \mathrm{~Hz}, 1 \mathrm{H}, \mathrm{H}-10), 8.73$ (dd, $J=9.2,2.3 \mathrm{~Hz}, 1 \mathrm{H}, \mathrm{H}-11), 8.06(\mathrm{~d}, J=8.8 \mathrm{~Hz}, 1 \mathrm{H}$, H-12), 8.02 (d, $J=7.8 \mathrm{~Hz}, 1 \mathrm{H}, \mathrm{H}-1), 7.93-7.91$ (m, 1H, H-7), 7.73 (br t, $J=8.3 \mathrm{~Hz}, 1 \mathrm{H}$, H-3), 7.68 (d, $J=15.7 \mathrm{~Hz}, 1 \mathrm{H}, \mathrm{H}-6), 7.69-7.64$ (m, 3H, H-2, H-8, H-9). ${ }^{13} \mathrm{C}$ NMR (125 $\mathrm{MHz}, \mathrm{CDCl}_{3}$ ): $\delta 160.0(\mathrm{~d}, J=252.7 \mathrm{~Hz}, \mathrm{C}-5), 132.9,132.3(\mathrm{~d}, J=11.4 \mathrm{~Hz}), 131.5(\mathrm{~d}, J=$ $5.5 \mathrm{~Hz}), 129.2(\mathrm{~d}, J=1.4 \mathrm{~Hz}, \mathrm{C}-12), 129.1(\mathrm{~d}, J=5.5 \mathrm{~Hz}), 128.7(\mathrm{C}-1), 128.04(\mathrm{~d}, J=1.1$ Hz), 128.0 (d, $J=26.6 \mathrm{~Hz}, \mathrm{C}-4), 127.7$ (d, $J=5.0 \mathrm{~Hz}, \mathrm{C}-7), 127.5$ (d, $J=3.2 \mathrm{~Hz}), 127.4$, 126.9 (d, $J=2.3 \mathrm{~Hz}), 126.0$ (d, $J=2.3 \mathrm{~Hz}), 123.6$ (d, $J=1.4 \mathrm{~Hz}, \mathrm{C}-10), 121.2$ (d, $J=3.2 \mathrm{~Hz}$, C-11), 120.1 (d, $J=11.9 \mathrm{~Hz}), 111.1$ (d, $J=24.7 \mathrm{~Hz}, \mathrm{C}-6) .{ }^{19} \mathrm{~F} \mathrm{NMR}\left(282 \mathrm{MHz}, \mathrm{CDCl}_{3}\right.$, resolution enhanced): $\delta-111.8$ (br dt, $J=15.7,3.3 \mathrm{~Hz}$ ).

\section{Synthesis of 5-Fluorobenzo[c]phenanthrene $5^{11 a, 15 a}$}

Step 1. Condensation of 2a with 2-naphthaldehyde-A solution of 2naphthaldehyde (393 mg, $2.51 \mathrm{mmol}$ ) and sulfone 2a (880 mg, $2.86 \mathrm{mmol}, 1.10$ molar equiv) in dry THF $(25.0 \mathrm{~mL})$ was cooled to $0{ }^{\circ} \mathrm{C}$ under a nitrogen atmosphere. LHMDS (6.50 mL, $6.50 \mathrm{mmol}, 2.40$ molar equiv) was added dropwise at $0{ }^{\circ} \mathrm{C}$. The mixture was stirred at $0{ }^{\circ} \mathrm{C}$ for $10 \mathrm{~min}$, allowed to warm to rt and stirred at rt. After $2 \mathrm{~h}$, TLC $(10 \%$ EtOAc in hexanes) showed complete disappearance of the aldehyde. Saturated aq $\mathrm{NH}_{4} \mathrm{Cl}(30$ $\mathrm{mL}$ ) was added and the mixture was extracted with EtOAc (3x). The combined organic layer was washed with $\mathrm{NaHCO}_{3}(30 \mathrm{~mL})$, brine $(30 \mathrm{~mL})$, and then dried over anhydrous $\mathrm{Na}_{2} \mathrm{SO}_{4}$. The solvent was evaporated under reduced pressure and the crude product was purified by column chromatography $\left(\mathrm{SiO}_{2}\right.$, eluted with hexanes, followed by $2 \%$ EtOAc in hexanes) to yield pure (E/Z)-2-(2-fluoro-2-phenylvinyl)naphthalene ${ }^{21}$ ( $E: Z$ ratio 2.9:1) as a yellowish solid (581 mg, 99\%). ${ }^{19} \mathrm{~F}$ NMR (282 MHz, $\left.\mathrm{CDCl}_{3}\right): \delta-96.2(\mathrm{~d}, J=18.3 \mathrm{~Hz}, 1 \mathrm{~F}),-114.4$ (d, $J=39.7 \mathrm{~Hz}, 1 \mathrm{~F}$ ). HRMS (+APPI mode) $[\mathrm{M}]^{+}$calcd. for $\mathrm{C}_{18} \mathrm{H}_{13} \mathrm{~F} 248.0996$, found 248.0995 .

\section{Step 2. Photocyclization of (E/Z)-2-(2-fluoro-2-phenylvinyl)naphthalene to} 5. 11a,15a_(E/Z)-2-(2-Fluoro-2-phenylvinyl)naphthalene ( $E: Z$ ratio 2.9:1, $60.0 \mathrm{mg}, 0.241$ $\mathrm{mmol})$ was dissolved in benzene $(250 \mathrm{~mL}), \mathrm{I}_{2}(64.4 \mathrm{mg}, 0.253 \mathrm{mmol}, 1.05$ molar equiv) was added, and nitrogen was bubbled into the solution for $10 \mathrm{~min}$. Propylene oxide $(2.80 \mathrm{~mL}$, $2.32 \mathrm{~g}, 40.0 \mathrm{mmol}, 166$ molar equiv) was added, the solution was subjected to irradiation, and the reaction was monitored by ${ }^{19} \mathrm{~F}$ NMR. After $12 \mathrm{~h},{ }^{19} \mathrm{~F}$ NMR showed consumption of 
(E/Z)-2-(2-fluoro-2-phenylvinyl)naphthalene. The solvent was evaporated and the crude product was purified by column chromatography $\left(\mathrm{SiO}_{2}, 2 \% \mathrm{CH}_{2} \mathrm{Cl}_{2}\right.$ in hexanes) to yield pure 5-fluorobenzo[c]phenanthrene 5 as a white solid (39.1 mg, 66\%). For X-ray analysis, this compound was crystallized from hexanes/2-3 drops of $\mathrm{CH}_{2} \mathrm{Cl}_{2} .{ }^{1} \mathrm{H} \mathrm{NMR}(500 \mathrm{MHz}$, $\mathrm{CDCl}_{3}$ ): $\delta 9.16(\mathrm{~d}, J=8.3 \mathrm{~Hz}, 1 \mathrm{H}), 9.07(\mathrm{~d}, J=8.3 \mathrm{~Hz}, 1 \mathrm{H}), 8.33(\mathrm{~d}, J=7.8 \mathrm{~Hz}, 1 \mathrm{H}), 8.03$ $(\mathrm{d}, J=7.8 \mathrm{~Hz}, 1 \mathrm{H}), 7.91(\mathrm{~d}, J=8.3 \mathrm{~Hz}, 1 \mathrm{H}), 7.77-7.68(\mathrm{~m}, 4 \mathrm{H}), 7.63(\mathrm{t}, J=7.8 \mathrm{~Hz}, 1 \mathrm{H})$, $7.49(\mathrm{~d}, J=10.6 \mathrm{~Hz}, 1 \mathrm{H}) .{ }^{13} \mathrm{C} \mathrm{NMR}\left(125 \mathrm{MHz}, \mathrm{CDCl}_{3}\right): \delta 157.4(\mathrm{~d}, J=252.7 \mathrm{~Hz}), 133.2$, $132.0(\mathrm{~d}, J=5.0 \mathrm{~Hz}), 131.2(\mathrm{~d}, J=9.2 \mathrm{~Hz}), 130.4,128.9,128.4,128.1$ (d, $J=2.8 \mathrm{~Hz}), 127.7$, $127.3,126.7,126.5(\mathrm{~d}, J=3.7 \mathrm{~Hz}), 126.4(\mathrm{~d}, J=1.4 \mathrm{~Hz}), 125.9,124.9(\mathrm{~d}, J=17.4 \mathrm{~Hz})$, 124.6 (d, $J=2.3 \mathrm{~Hz}), 121.3$ (d, $J=6.4 \mathrm{~Hz}), 108.9$ (d, $J=20.1 \mathrm{~Hz}) .{ }^{19} \mathrm{~F}$ NMR $(282 \mathrm{MHz}$, $\left.\mathrm{CDCl}_{3}\right): \delta-125.4(\mathrm{~d}, J=9.2 \mathrm{~Hz})$.

\section{Synthesis of 6-Fluorobenzo[c]phenanthrene $6^{11 a, 15 a, 17}$}

Step 1. Condensation of $2 c$ with benzaldehyde-A solution of benzaldehyde (228 $\mathrm{mg}, 2.15 \mathrm{mmol}$ ) and sulfone $2 \mathbf{c}$ ( $920 \mathrm{mg}, 2.58 \mathrm{mmol}, 1.20$ molar equiv) in dry THF ( $28 \mathrm{~mL}$ ) was cooled to $0{ }^{\circ} \mathrm{C}$ under a nitrogen atmosphere. LHMDS $(5.15 \mathrm{~mL}, 5.15 \mathrm{mmol}, 2.40$ molar equiv) was added dropwise at $0{ }^{\circ} \mathrm{C}$ and the mixture was stirred at $0{ }^{\circ} \mathrm{C}$. After $2 \mathrm{~h}, \mathrm{TLC}(10 \%$ EtOAc in hexanes) showed complete disappearance of the aldehyde. Saturated aq $\mathrm{NH}_{4} \mathrm{Cl}(30$ $\mathrm{mL}$ ) was added and the mixture was extracted with EtOAc (3x). The combined organic layer was washed with $\mathrm{NaHCO}_{3}(30 \mathrm{~mL})$, brine $(30 \mathrm{~mL})$, and then dried over anhydrous $\mathrm{Na}_{2} \mathrm{SO}_{4}$. The solvent was evaporated under reduced pressure and the crude product was purified by column chromatography $\left(\mathrm{SiO}_{2}\right.$, eluted with 5\% EtOAc in hexanes) to yield pure (E/Z)-2-(1fluoro-2-phenylvinyl)naphthalene ( $E: Z$ ratio $2.75: 1)$ as an off-white solid $(460 \mathrm{mg}$, 76\%). ${ }^{19} \mathrm{~F}$ NMR (282 MHz, $\left.\mathrm{CDCl}_{3}\right): \delta-96.6(\mathrm{~d}, J=21.4 \mathrm{~Hz}, 1 \mathrm{~F})$ and $-114.9(\mathrm{~d}, J=39.7$ $\mathrm{Hz}, 1 \mathrm{~F}$ ). HRMS (+APPI mode) [M] ${ }^{+}$calcd. for $\mathrm{C}_{18} \mathrm{H}_{13} \mathrm{~F} 248.0996$, found 248.0999 .

\section{Step 2. Photocyclization of (E/Z)-2-(1-fluoro-2-phenylvinyl)naphthalene to} 6. ${ }^{11 a, 15 a, 17}$-(E/Z)-2-(1-fluoro-2-phenylvinyl)naphthalene ( $E: Z$ ratio $2.75: 1,127 \mathrm{mg}, 0.512$ $\mathrm{mmol}$ ) was dissolved in benzene $(250 \mathrm{~mL}), \mathrm{I}_{2}(144 \mathrm{mg}, 0.567 \mathrm{mmol}, 1.11$ molar equiv) was added, and nitrogen was bubbled into the solution for $10 \mathrm{~min}$. Propylene oxide $(7.17 \mathrm{~mL}$, $5.95 \mathrm{~g}, 102 \mathrm{mmol}, 200$ molar equiv) was added, the solution was subjected to irradiation, and the reaction was monitored by ${ }^{19} \mathrm{~F}$ NMR. After $26 \mathrm{~h},{ }^{19} \mathrm{~F}$ NMR showed consumption of the alkene. The solvent was evaporated and the crude product was purified by column chromatography $\left(\mathrm{SiO}_{2}, 2.5 \%\right.$ EtOAc in hexanes) to yield pure 6-fluorobenzo[c]phenanthrene 6 as a white solid (105 mg, 83\%). For X-ray analysis, this compound was crystallized from hexanes/2-3 drops of $\mathrm{CH}_{2} \mathrm{Cl}_{2}$, m.p. $72-73{ }^{\circ} \mathrm{C} .{ }^{1} \mathrm{H} \mathrm{NMR}\left(500 \mathrm{MHz}, \mathrm{CDCl}_{3}\right): \delta 9.12$ (d, $J=$ $8.3 \mathrm{~Hz}, 1 \mathrm{H}), 9.10(\mathrm{~d}, J=9.2 \mathrm{~Hz}, 1 \mathrm{H}), 8.17(\mathrm{~d}, J=8.8 \mathrm{~Hz}, 1 \mathrm{H}), 8.06(\mathrm{~d}, J=7.8 \mathrm{~Hz}, 1 \mathrm{H})$, $7.99-7.95(\mathrm{~m}, 2 \mathrm{H}), 7.73-7.66(\mathrm{~m}, 3 \mathrm{H}), 7.63(\mathrm{t}, J=3.5 \mathrm{~Hz}, 1 \mathrm{H}), 7.56(\mathrm{~d}, J=10.6 \mathrm{~Hz}$, $1 \mathrm{H}) .{ }^{13} \mathrm{C} \mathrm{NMR}\left(125 \mathrm{MHz}, \mathrm{CDCl}_{3}\right): \delta 157.2(\mathrm{~d}, J=251.3 \mathrm{~Hz}), 133.9,133.3(\mathrm{~d}, J=10.6 \mathrm{~Hz})$, $130.1(\mathrm{~d}, J=2.8 \mathrm{~Hz}), 129.5(\mathrm{~d}, J=4.8 \mathrm{~Hz}), 129.0,128.3$ (one resonance of the doublet partially buried under a singlet), 128.24, 128.22, 128.19, 128.0, 126.78, 126.77, 126.73, 125.5 (d, $J=1.9 \mathrm{~Hz}), 123.0$ (d, $J=18.2 \mathrm{~Hz}), 118.7$ (d, $J=8.6 \mathrm{~Hz}), 109.1$ (d, $J=20.1$

Hz). $\left.{ }^{19} \mathrm{~F} \mathrm{NMR} \mathrm{(282} \mathrm{MHz,} \mathrm{CDCl}_{3}\right): \delta-125.8(\mathrm{~d}, J=12.2 \mathrm{~Hz})$. 


\section{Synthesis of 10-Fluorobenzo[ $g]$ chrysene 7}

Step 1. Condensation of $2 \mathrm{a}$ with phenanthrene-9-carboxaldehyde-A solution of phenanthrene-9-carboxaldehyde (79.7 mg, $0.386 \mathrm{mmol}$ ) and sulfone $2 \mathbf{a}(149 \mathrm{mg}, 0.459$ mmol, 1.19 molar equiv) in dry THF $(10 \mathrm{~mL})$ was cooled to $0{ }^{\circ} \mathrm{C}$ under a nitrogen atmosphere. LHMDS $\left(0.90 \mathrm{~mL}, 0.90 \mathrm{mmol}, 2.33\right.$ molar equiv) was added dropwise at $0{ }^{\circ} \mathrm{C}$. The mixture was stirred at $0{ }^{\circ} \mathrm{C}$ for $10 \mathrm{~min}$, allowed to warm to $\mathrm{rt}$ and stirred at rt. After $1 \mathrm{~h}$, TLC (5\% EtOAc in hexanes) showed complete disappearance of the aldehyde. Saturated aq $\mathrm{NH}_{4} \mathrm{Cl}(30 \mathrm{~mL})$ was added and the mixture was extracted with EtOAc (3x). The combined organic layer was washed with $\mathrm{NaHCO}_{3}(30 \mathrm{~mL})$, brine $(30 \mathrm{~mL})$, and then dried over anhydrous $\mathrm{Na}_{2} \mathrm{SO}_{4}$. The solvent was evaporated under reduced pressure and the crude product was purified by column chromatography $\left(\mathrm{SiO}_{2}\right.$, eluted with $5 \%$ EtOAc in hexanes) to yield pure (E/Z)-9-(2-fluoro-2-phenylvinyl)phenanthrene ( $E$ : $Z$ ratio 3.1:1) as a colorless liquid $(80.7 \mathrm{mg}, 70 \%) .{ }^{19} \mathrm{~F} \mathrm{NMR}\left(282 \mathrm{MHz}, \mathrm{CDCl}_{3}\right): \delta-100.3(\mathrm{~d}, J=21.4 \mathrm{~Hz}, 1 \mathrm{~F}),-115.2$ (d, $J=36.6 \mathrm{~Hz}, 1 \mathrm{~F}$ ). HRMS (+APPI mode) $[\mathrm{M}]^{+}$calcd. for $\mathrm{C}_{22} \mathrm{H}_{15} \mathrm{~F} 298.1152$, found 298.1159 .

Step 2. Photocyclization of (E/Z)-9-(2-fluoro-2-phenylvinyl)phenanthrene to 7(E/Z)-9-(2-Fluoro-2-phenylvinyl)phenanthrene ( $E: Z$ ratio $3.1: 1,80.7 \mathrm{mg}, 0.270 \mathrm{mmol}$ ) was dissolved in benzene $(250 \mathrm{~mL}), \mathrm{I}_{2}(84.1 \mathrm{mg}, 0.331 \mathrm{mmol}, 1.23$ molar equiv) was added, and nitrogen was bubbled into the solution for $10 \mathrm{~min}$. Propylene oxide $(3.12 \mathrm{~mL}, 2.59 \mathrm{~g}, 44.6$ mmol, 165 molar equiv) was added, the solution was subjected to irradiation, and the reaction was monitored by ${ }^{19} \mathrm{~F}$ NMR. After $8.5 \mathrm{~h},{ }^{19} \mathrm{~F}$ NMR showed consumption of ( $E /$ $Z$ )-9-(2-fluoro-2-phenylvinyl)phenanthrene. The solvent was evaporated and the crude product was purified by column chromatography $\left(\mathrm{SiO}_{2}, 4 \%\right.$ EtOAc in hexanes) to yield pure 10-fluorobenzo[ $g]$ chrysene 7 as a white solid $(61.3 \mathrm{mg}, 77 \%)$. For X-ray analysis, this compound was crystallized from hexanes/2-3 drops of $\mathrm{CH}_{2} \mathrm{Cl}_{2}$, m.p. $141^{\circ} \mathrm{C} .{ }^{1} \mathrm{H}$ NMR $(500$ $\left.\mathrm{MHz}, \mathrm{CDCl}_{3}\right): \delta 8.95(\mathrm{~d}, J=7.4 \mathrm{~Hz}, 1 \mathrm{H}), 8.81(\mathrm{~d}, J=7.8 \mathrm{~Hz}, 1 \mathrm{H}), 8.72(\mathrm{~d}, J=8.3 \mathrm{~Hz}, 1 \mathrm{H})$, 8.71-8.68 (m, 1H), 8.50-8.48 (m, 1H), 8.31-8.29 (m, 1H), 8.24 (d, J=12.4 Hz, 1H, H-9), $7.72-7.62(\mathrm{~m}, 6 \mathrm{H}) .{ }^{13} \mathrm{C}$ NMR $\left(125 \mathrm{MHz}, \mathrm{CDCl}_{3}\right): \delta 158.3(\mathrm{~d}, J=251.7 \mathrm{~Hz}, \mathrm{C}-10), 131.9(\mathrm{~d}$, $J=5.0 \mathrm{~Hz}), 130.7,130.4,129.5(\mathrm{~d}, J=3.5 \mathrm{~Hz}), 129.4,129.2,128.7(\mathrm{~d}, J=2.7 \mathrm{~Hz}), 127.8$, 127.6, 127.2, 126.7, 126.5, 126.4, 124.6 (d, $J=17.4 \mathrm{~Hz}$ ), 124.3 (d, $J=2.6 \mathrm{~Hz}), 124.0,123.7$, 123.4, 121.0 (d, $J=5.5 \mathrm{~Hz}), 104.1$ (d, $J=21.5 \mathrm{~Hz}, \mathrm{C}-9) .{ }^{19} \mathrm{~F} \mathrm{NMR}\left(282 \mathrm{MHz}, \mathrm{CDCl}_{3}\right): \delta$ $-124.3\left(\mathrm{~d}, J=12.2 \mathrm{~Hz}\right.$ ). HRMS (+APPI mode) $[\mathrm{M}]^{+}$calcd. for $\mathrm{C}_{22} \mathrm{H}_{13} \mathrm{~F} 296.0996$, found 296.0998.

\section{Synthesis of 9-Fluorobenzo[g]chrysene 8}

Step 1. Condensation of $\mathbf{2 d}$ with benzaldehyde-A solution of benzaldehyde (59.7 $\mathrm{mg}, 0.563 \mathrm{mmol})$ and sulfone $\mathbf{2 d}(270 \mathrm{mg}, 0.664 \mathrm{mmol}, 1.18$ molar equiv) in dry THF (10 $\mathrm{mL}$ ) was cooled to $0{ }^{\circ} \mathrm{C}$ under a nitrogen atmosphere. LHMDS $(1.40 \mathrm{~mL}, 1.40 \mathrm{mmol}, 2.49$ molar equiv) was added dropwise at $0{ }^{\circ} \mathrm{C}$. The mixture was stirred at $0{ }^{\circ} \mathrm{C}$ for $10 \mathrm{~min}$, allowed to warm to rt and stirred at rt. After $1 \mathrm{~h}$, TLC (10\% EtOAc in hexanes) showed complete disappearance of the aldehyde. Saturated aq $\mathrm{NH}_{4} \mathrm{Cl}(30 \mathrm{~mL})$ was added and the mixture was extracted with EtOAc (3x). The combined organic layer was washed with $\mathrm{NaHCO}_{3}(30 \mathrm{~mL})$, brine $(30 \mathrm{~mL})$, and then dried over anhydrous $\mathrm{Na}_{2} \mathrm{SO}_{4}$. The solvent was evaporated under reduced pressure and the crude product was purified by column 
chromatography ( $\mathrm{SiO}_{2}$, eluted with 5\% EtOAc in hexanes) to yield pure (E/Z)-9-(1-fluoro-2phenylvinyl)phenanthrene (E:Z ratio 2.88:1) as a colorless liquid (149 mg, 89\%). ${ }^{19} \mathrm{~F}$ NMR (282 MHz, $\left.\mathrm{CDCl}_{3}\right): \delta-85.0(\mathrm{~d}, J=21.4 \mathrm{~Hz}, 1 \mathrm{~F}),-95.3(\mathrm{~d}, J=36.6 \mathrm{~Hz}, 1 \mathrm{~F})$. HRMS (+APPI mode) $[\mathrm{M}]^{+}$calcd. for $\mathrm{C}_{22} \mathrm{H}_{15} \mathrm{~F} 298.1152$, found 298.1151 .

\section{Step 2. Photocyclization of (E/Z)-9-(1-fluoro-2-phenylvinyl)phenanthrene to 8-} (E/Z)-9-(1-Fluoro-2-phenylvinyl)phenanthrene ( $E: Z$ ratio $2.88: 1,76.1 \mathrm{mg}, 0.255 \mathrm{mmol}$ ) was dissolved in benzene ( $250 \mathrm{~mL}), \mathrm{I}_{2}(71.3 \mathrm{mg}, 0.281 \mathrm{mmol}, 1.10$ molar equiv) was was added, and nitrogen was bubbled into the solution for $10 \mathrm{~min}$. Propylene oxide $(2.80 \mathrm{~mL}, 2.32 \mathrm{~g}$, $40.0 \mathrm{mmol}, 157$ molar equiv) was added, the solution was subjected to irradiation, and the reaction was monitored by ${ }^{19} \mathrm{~F}$ NMR. After $8 \mathrm{~h},{ }^{19} \mathrm{~F}$ NMR showed consumption of the alkene. The solvent was evaporated and the crude product was purified by column chromatography $\left(\mathrm{SiO}_{2}, 2 \%\right.$ EtOAc in hexanes) to yield pure 9-fluorobenzo $[g]$ chrysene $\mathbf{8}$ as a white solid (55.1 mg, 73\%). For X-ray analysis, this compound was crystallized from EtOH/2-3 drops of benzene/1 drop of $\mathrm{CH}_{2} \mathrm{Cl}_{2} \cdot{ }^{1} \mathrm{H} \mathrm{NMR}\left(500 \mathrm{MHz}, \mathrm{CDCl}_{3}\right.$ ): $\delta 9.07$ (dt, $J=$ $8.1,2.2 \mathrm{~Hz}, 1 \mathrm{H}, \mathrm{H}-8), 8.82(\mathrm{~d}, J=8.3 \mathrm{~Hz}, 1 \mathrm{H}), 8.79(\mathrm{~d}, J=8.3 \mathrm{~Hz}, 1 \mathrm{H}), 8.71(\mathrm{~d}, J=8.8 \mathrm{~Hz}$, 2H), 7.94 (d, $J=7.4 \mathrm{~Hz}, 1 \mathrm{H}, \mathrm{H}-11), 7.75-7.70$ (m, 3H), 7.67 (d, $J=15.2 \mathrm{~Hz}, 1 \mathrm{H}, \mathrm{H}-10$ ), 7.65-7.55 (m, 3H). ${ }^{13} \mathrm{C}$ NMR (125 MHz, $\left.\mathrm{CDCl}_{3}\right): \delta 159.3$ (d, $\left.J=251.7 \mathrm{~Hz}, \mathrm{C}-9\right), 133.2(\mathrm{~d}, J$ $=11.0 \mathrm{~Hz}), 131.5,131.3(\mathrm{~d}, J=4.1 \mathrm{~Hz}), 130.4,130.1,129.2(\mathrm{~d}, J=2.4 \mathrm{~Hz}), 129.0,128.0(\mathrm{~d}$, $J=26.1 \mathrm{~Hz}, \mathrm{C}-8), 127.8,127.7,127.6,127.4,127.2$ (d, $J=5.0 \mathrm{~Hz}, \mathrm{C}-11), 126.9,126.4$, 125.2, 123.8, 123.1, 119.9 (d, $J=11.5 \mathrm{~Hz}, \mathrm{C}-10 \mathrm{a}), 111.3$ (d, $J=24.7 \mathrm{~Hz}, \mathrm{C}-10) .{ }^{19}$ F NMR (282 MHz, $\mathrm{CDCl}_{3}$, resolution enhanced): $\delta-114.6 \mathrm{ppm}$ (dd, $J=15.1 ; 2.3 \mathrm{~Hz}$ ). HRMS (+APPI mode) $[\mathrm{M}]^{+}$calcd. for $\mathrm{C}_{22} \mathrm{H}_{13} \mathrm{~F} 296.0996$, found 296.1002 .

\section{Supplementary Material}

Refer to Web version on PubMed Central for supplementary material.

\section{Acknowledgments}

This work was supported by National Science Foundation Grant CHE-1058618, partially by NIH (NIGMS) Grant S06 GM008168, and by PSC CUNY awards. Infrastructural support was provided by National Institutes of Health Grant 8G12MD007603 from the National Institute on Minority Health and Health Disparities. We thank Dr. Andrew Poss (Honeywell) for a sample of NFSI, and Dr. Sakilam Satishkumar for his assistance with obtaining some NMR spectra. We thank Ms. Wei Wei, Ms. Marikone Gaši, and Mr. Michael Benavidez for resynthesis of 1styrylnaphthalene and (E/Z)-1-(2-fluoro-2-phenylvinyl)naphthalene for the UV measurements, and Ms. Karen Lo for obtaining the UV spectra of these alkenes. We thank Mr. Satish Lakshman (Pixiedust) for the final design of the cover art and Professor Mahesh Lakshman (CCNY) for his help and advice with the musical aspects represented in the cover art.

\section{References}

1. (a) Kirsch, P. Modern Fluoroorganic Chemistry. Synthesis, Reactivity, Applications. Wiley-VCH Verlag GmbH \& Co. KGaA; 2004. (b) Okazaki, T.; Laali, KK. Fluorinated polycyclic aromatic hydrocarbons (PAHs) and heterocyclic aromatic hydrocarbons (hetero-PAHs); synthesis and utility. In: Laali, KK., editor. Modern Organofluorine Chemistry-Synthetic Aspects. Vol. 2. Bentham Science Publishers; 2006. p. 353-380.

2. (a) Kirsch P, Bremer M. Angew Chem, Int Ed. 2000; 39:4216-4235.(b) Babudri F, Farinola GM, Naso F, Ragni R. Chem Commun. 2007:1003-1022.(c) Berger R, Resnati G, Metrangolo P, Weber E, Hulliger J. Chem Soc Rev. 2011; 40:3496-3508. [PubMed: 21448484] (d) Xu T, Yu L. Mater Today. 2014; 17:11-15. 
3. (a) Andersson JT, Weis U. J Chromatogr A. 1994; 659:151-161.(b) Luthe G, Ramos L, Dallüge J, Brinkman UATh. Chromatographia. 2003; 57:379-383.

4. Harvey, RG. Polycyclic Aromatic Hydrocarbons: Chemistry and Carcinogenicity;. Cambridge University Press; Cambridge: 1991.

5. Jerina, DM.; Sayer, JM.; Agarwal, SK.; Yagi, H.; Levin, W.; Wood, AW.; Conney, AH.; PruessSchwartz, D.; Baird, WM.; Pigott, MA.; Dipple, A. Reactivity and tumorigenicity of bay-region diol epoxides derived from polycyclic aromatic hydrocarbons. In: Kocsis, JJ.; Jollow, DJ.; Witmer, CM.; Nelson, JO.; Snyder, R., editors. Biological Reactive Intermediates III. Plenum Press; New York: 1986. p. 11-30.

6. (a) Jerina, DM.; Chadha, A.; Cheh, AM.; Schurdak, ME.; Wood, AW.; Sayer, JM. Covalent bonding of bay-region diol epoxides to nucleic acids. In: Witmer, CM.; Snyder, R.; Jollow, DJ.; Kalf, GF.; Kocsis, JJ.; Sipes, IG., editors. Biological Reactive Intermediates IV. Plenum Press; New York: 1991. p. 533-553.(b) Dipple, A. Reactions of polycyclic aromatic hydrocarbons with DNA. In: Hemminki, K.; Dipple, A.; Shuker, DEG.; Kadlubar, FF.; Sagerbäck, D.; Bartsch, H., editors. DNA Adducts: Identification and Biological Significance. International Agency for Research on Cancer; Lyon: 1994. p. 107-129.Scientific Publication No. 125(c) Szeliga J, Dipple A. Chem Res Toxicol. 1998; 11:1-11. [PubMed: 9477220]

7. (a) Penning TM, Burczynski ME, Hung CF, McCoull KD, Palackal NT, Tsuruda LS. Chem Res Toxicol. 1999; 12:1-18. [PubMed: 9894013] (b) Bolton JL, Trush MA, Penning TM, Dryhurst G, Monks TJ. Chem Res Toxicol. 2000; 13:135-160. [PubMed: 10725110]

8. (a) Jerina, DM.; Sayer, JM.; Yagi, H.; Croisy-Delcey, M.; Ittah, Y.; Thakker, DR.; Wood, AW.; Chang, RL.; Levin, W.; Conney, AH. Highly tumorigenic bay-region diol epoxides from the weak carcinogen benzo[c]phenanthrene. In: Snyder, R.; Parke, DV.; Kocsis, JJ.; Jollow, DJ.; Gibson, CG.; Witmer, CM., editors. Biological Reactive Intermediates II Part A. Plenum Press; New York: 1982. p. 501-523.(b) Prasad GKB, Mirsadeghi S, Boehlert C, Byrd RA, Thakker DR. J Biol Chem. 1988; 263:3676-3683. [PubMed: 3346217]

9. (a) Buhler DR, Unlu F, Thakker DR, Slaga TJ, Conney AH, Wood AW, Chang RL, Levin W, Jerina DM. Cancer Res. 1983; 43:1541-1549. [PubMed: 6299523] (b) Chang RL, Wood AW, Conney AH, Yagi H, Sayer JM, Thakker DR, Jerina DM, Levin W. Proc Natl Acad Sci USA. 1987; 84:86338636. [PubMed: 3479808] (c) Cavalieri E, Rogan E, Higginbotham S, Cremonesi P, Salmasi S. J Cancer Res Clin Oncol. 1988; 114:10-15. [PubMed: 3350835] (d) Cavalieri E, Rogan E, Higginbotham S, Cremonesi P, Salmasi S. J Cancer Res Clin Oncol. 1988; 114:16-22. [PubMed: 3350838]

10. Bae S, Mah H, Chaturvedi S, Musafia TJ, Baird WM, Katz AK, Carrell HL, Glusker JP, Okazaki T, Laali KK, Zajc B, Lakshman MK. J Org Chem. 2007; 72:7625-7633. [PubMed: 17764198]

11. (a) Mirsadeghi S, Prasad GKB, Whittaker N, Thakker DR. J Org Chem. 1989; 54:3091-3096.(b) Laali KK, Hansen PE. J Org Chem. 1993; 58:4096-4104.(c) Fakuhara T, Sekiguchi M, Yoneda N. Chem Lett. 1994:1011-1012.(d) Yang T, Huang Y, Cho BP. Chem Res Toxicol. 2006; 19:242-254. [PubMed: 16485900]

12. (a) Laali KK, Tanaka M, Forohar F, Cheng M, Fetzer JC. J Fluorine Chem. 1998; 91:185-190.(b) Zajc, B. Application of xenon difluoride in synthesis. In: Laali, K., editor. Modern Organofluorine Chemistry-Synthetic Aspects. Vol. 2. Bentham Science Publishers; 2006. p. 61-157.

13. Zajc B. J Org Chem. 1999; 64:1902-1907. [PubMed: 11674280]

14. (a) Girke W, Bergmann ED. Chem Ber. 1976; 109:1038-1045.(b) Harvey RG, Cortez C. Tetrahedron. 1997; 53:7101-7118.

15. (a) Marx GS, Bergmann ED. J Org Chem. 1972; 37:1807-1810.(b) Ittah Y, Jerina DM. J Fluorine Chem. 1980; 16:137-144.(c) Weis U, Andersson JT. Polycycl Aromat Comp. 2002; 22:71-85.(d) Li H, He KH, Liu J, Wang BQ, Zhao KQ, Hu P, Shi ZJ. Chem Commun. 2012; 48:7028-7030.(e) Li Z, Twieg RJ. Chem Eur J. 2015; 21:15534-15539. [PubMed: 26360126]

16. (a) Furuya T, Ritter T. J Am Chem Soc. 2008; 130:10060-10061. [PubMed: 18616246] (b) Lee HG, Milner PJ, Buchwald SL. J Am Chem Soc. 2014; 136:3792-3795. [PubMed: 24559304] (c) Fuchibe K, Morikawa T, Shigeno K, Fujita T, Ichikawa J. Org Lett. 2015; 17:1126-1129. [PubMed: 25686405] 
17. Synthesis of several F-PAHs, including 9-fluorophenanthrene, 5- and 6-fluorochrysene, 6fluorobenzo[c]phenanthrene, and 5-fluorobenzo[k]chrysene: Fuchibe K, Mayumi Y, Zhao N, Watanabe S, Yokota M, Ichikawa J. Angew Chem, Int Ed. 2013; 52:7825-7828.

18. (a) Blakemore PR. J Chem Soc, Perkin Trans I. 2002:2563-2585.(b) Plesniak K, Zarecki A, Wicha J. Top Curr Chem. 2007; 275:163-250. [PubMed: 23605513] (c) Aïssa C. Eur J Org Chem. 2009:1831-1844.

19. For reviews on fluoroolefination using the Julia-Kocienski approach, see: Zajc B, Kumar R. Synthesis. 2010:1822-1836. [PubMed: 22544979] Pfund E, Lequeux T, Gueyrard D. Synthesis. $2015 ; 47: 1534-1546$.

20. For our recent efforts in this area, see: Kumar R, Pradhan P, Zajc B. Chem Commun. 2011; 47:3891-3893.Mandal SK, Ghosh AK, Kumar R, Zajc B. Org Biomol Chem. 2012; 10:31643167. [PubMed: 22349519] Kumar R, Zajc B. J Org Chem. 2012; 77:8417-8427. [PubMed: 23005035] Chowdhury M, Mandal SK, Banerjee S, Zajc B. Molecules. 2014; 19:4418-4432. [PubMed: 24727415] Kumar R, Singh G, Todaro LJ, Yang L, Zajc B. Org Biomol Chem. 2015; 13:1536-1549. [PubMed: 25491086]

21. Ghosh AK, Zajc B. Org Lett. 2006; 8:1553-1556. [PubMed: 16597108]

22. (a) Laarhoven WH. Recl Trav Chim Pays-Bas. 1983; 102:185-204.(b) Mallory FB, Mallory CW. Org Reactions. 1984; 30:1-456.(c) Jørgensen KB. Molecules. 2010; 15:4334-4358. [PubMed: 20657445]

23. Liu L, Yang B, Katz TJ, Poindexter MK. J Org Chem. 1991; 56:3769-3775.

24. Alacid E, Nájera C. Adv Synth Cat. 2006; 348:2085-2091.

25. Lackner B, Bretterbauer K, Schwarzinger C, Falk H. Monatsh Chem. 2005; 136:2067-2082.

26. Nayak SK, Reddy MK, Chopra D, Row TNG. CrystEngComm. 2012; 14:200-210.

27. Champagne PA, Desroches J, Paquin JF. Synthesis. 2015; 47:306-322.

28. Arunan E, Desiraju GR, Klein RA, Sadlej J, Scheiner S, Alkorta I, Clary DC, Crabtree RH, Dannenberg JJ, Hobza P, Kjaergaard HG, Legon AC, Mennucci B, Nesbitt DJ. Pure Appl Chem. 2011; 83:1619-1636.

29. Laali KK, Okazaki T. J Org Chem. 2001; 66:780-788. [PubMed: 11430096]

30. Lutnaes BF, Luthe G, Brinkman UATh, Johansen JE, Krane J. Magn Reson Chem. 2005; 43:588594. and references therein. [PubMed: 15809969]

31. See for example: Mallory FB, Mallory CW. Coupling through space in organic chemistry. Encyclopedia of Nuclear Magnetic Resonance. Grant DM, Harris RK. J. Wiley \& SonsChichester1996; 3:1491-1501.Online 2007 John Wiley \& Sons, LtdHierso JC. Chem Rev. 2014; 114:4838-4867. [PubMed: 24533483]

32. Mallory FB, Mallory CW, Ricker WM. J Am Chem Soc. 1975; 97:4770-4771.

33. Sardella DJ, Boger E. Magn Res Chem. 1989; 27:13-20.

34. Thalladi VR, Weiss HC, Bläser D, Boese R, Nangia A, Desiraju GR. J Am Chem Soc. 1998; 120:8702-8710.

35. Laali KK, Hollenstein S, Harvey RG, Hansen PE. J Org Chem. 1997; 62:4023-4028. 

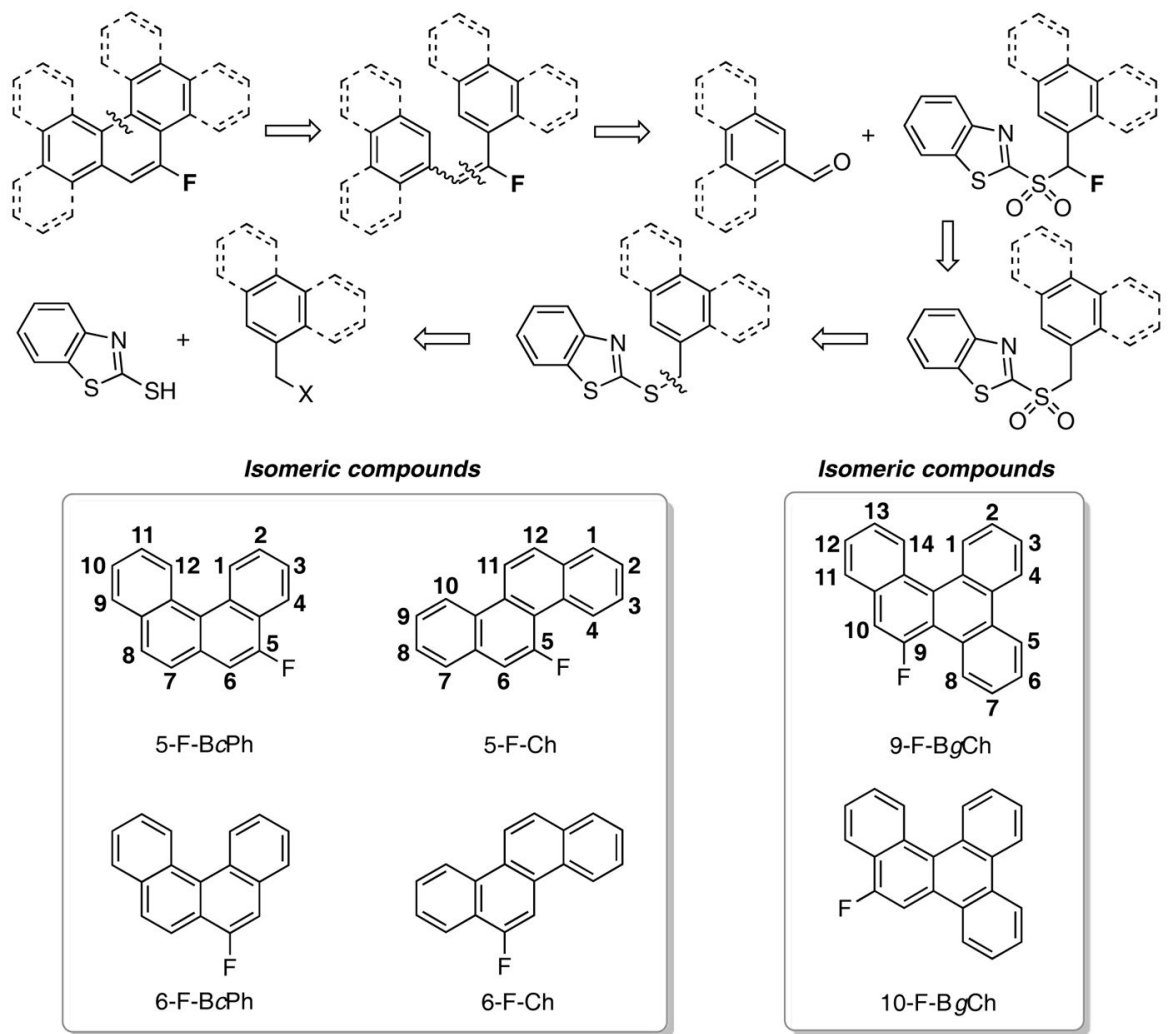

Isomeric compounds

FIGURE 1.

Retrosynthetic route to regiospecifically fluorinated PAHs via Julia olefination and oxidative photocyclization, and structures of the targets selected for this work. 


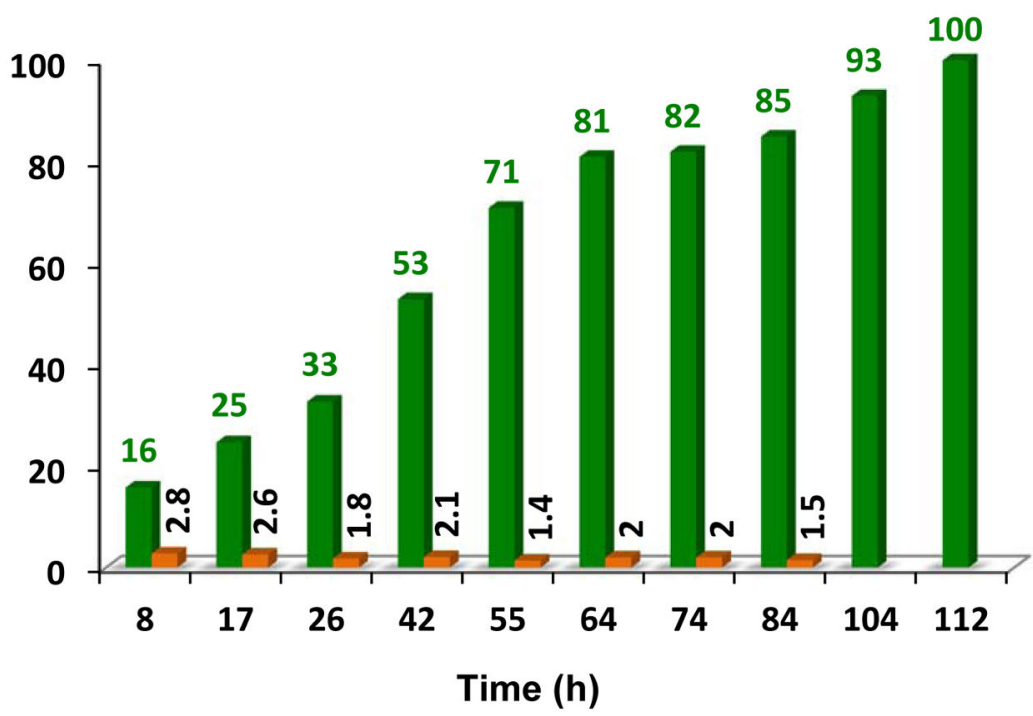

FIGURE 2.

Formation of 6-F-Ch (\% conversion in green bars and the $E / Z$ fluoroalkene ratio in orange bars). Reaction was monitored by ${ }^{19} \mathrm{~F}$ NMR. 


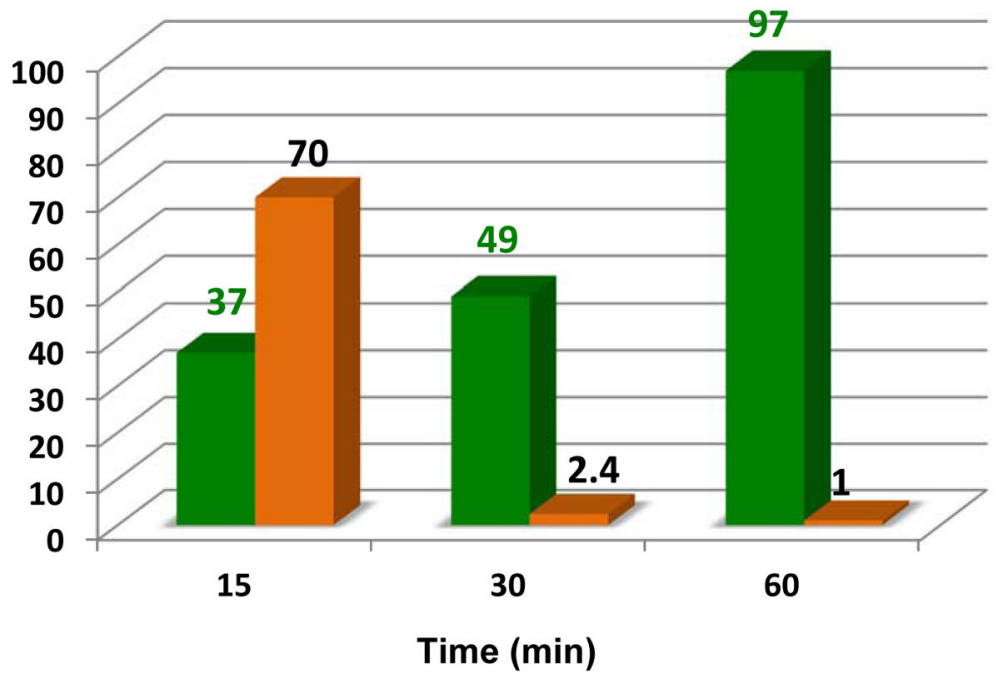

FIGURE 3.

Formation of chrysene (\% conversion in green bars and the $E / Z$ alkene ratio in orange bars). 

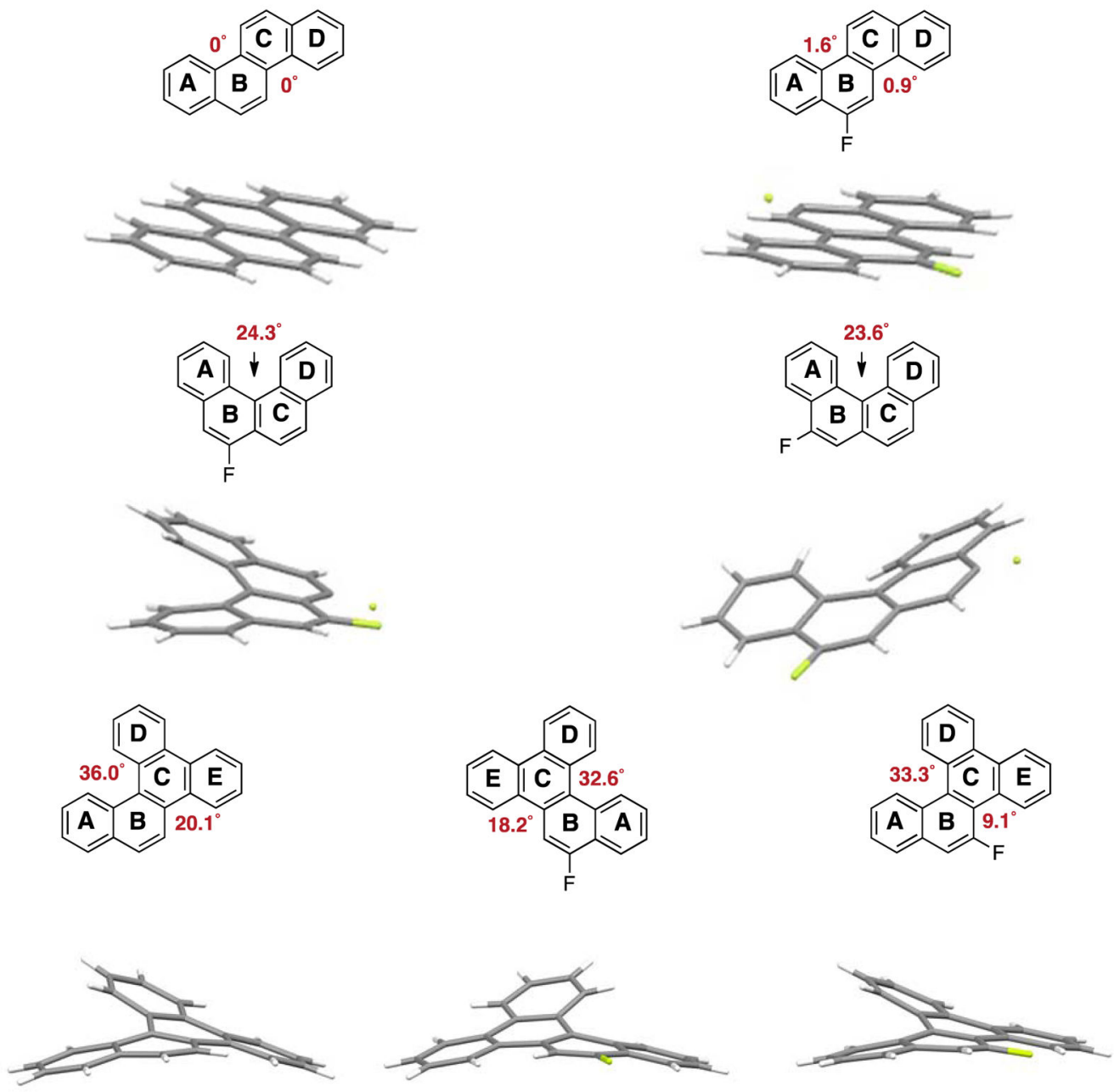

FIGURE 4.

Crystal structures of PAHs and F-PAHs obtained in this work (C, gray; H, white; F, green). 


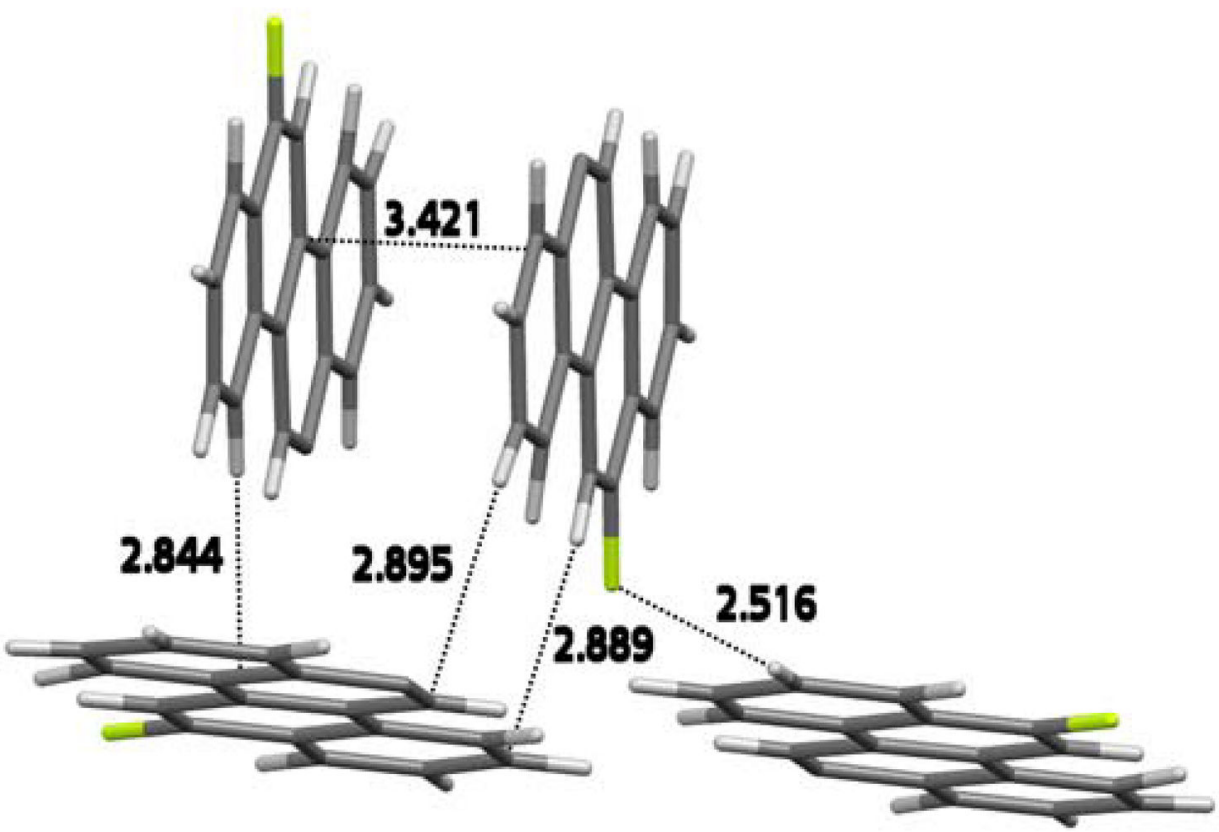

FIGURE 5.

Intermolecular interactions in the X-ray crystal structure of 6-F-Ch (3) (our data). 


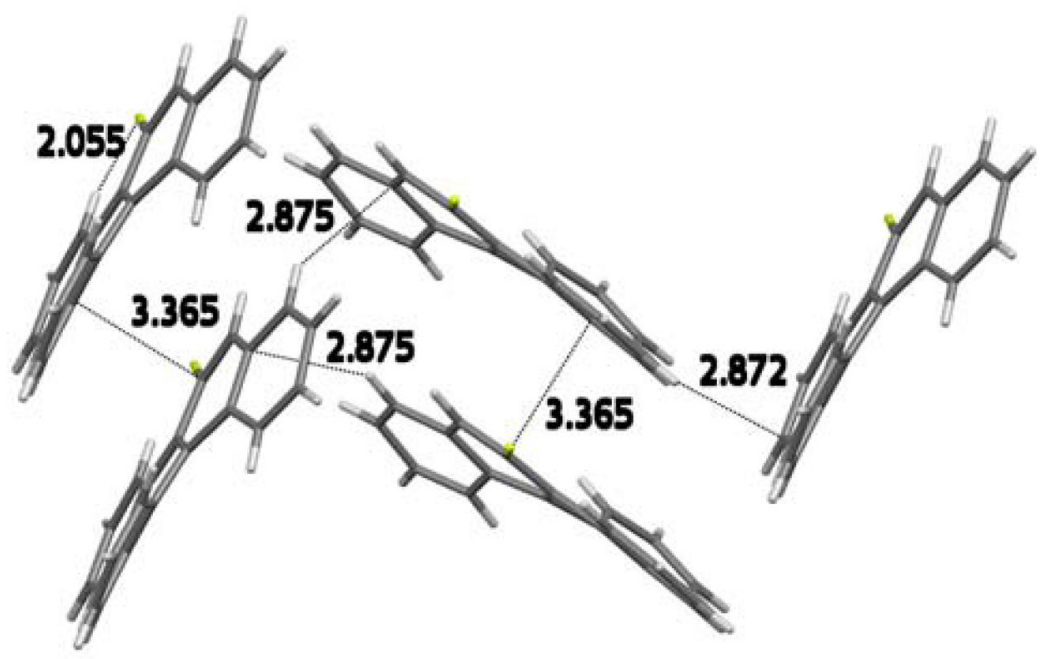

FIGURE 6.

Intermolecular interactions in the X-ray crystal structure of 9-F-BgCh (8). 

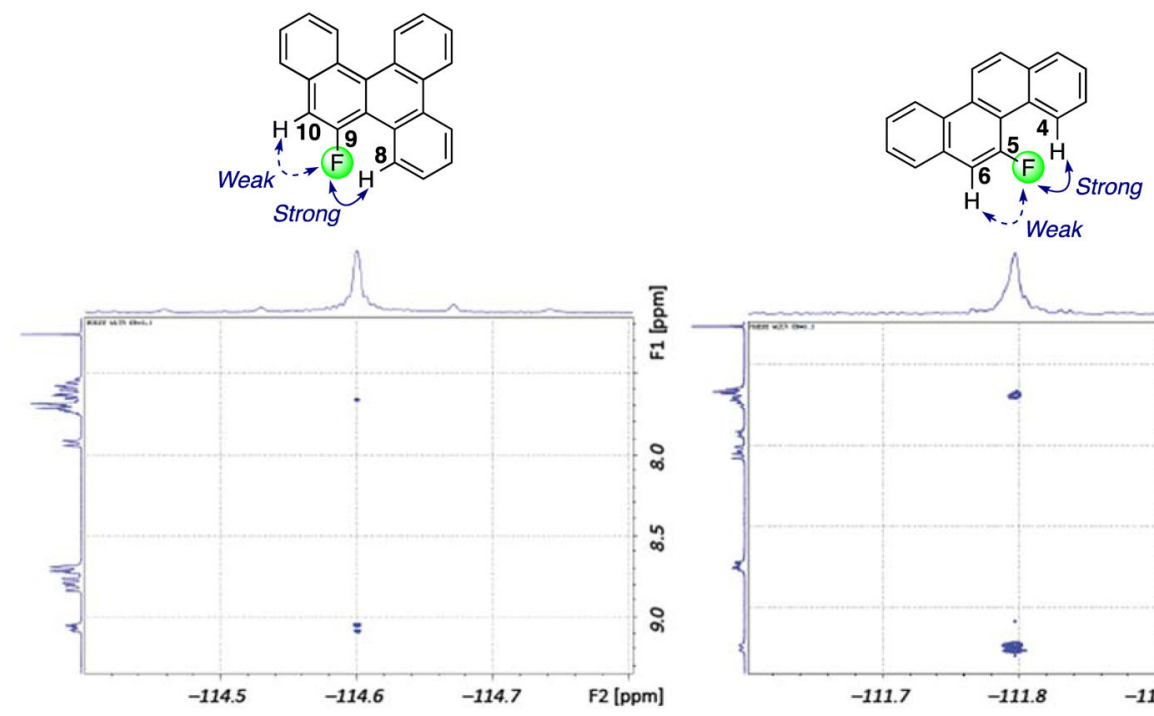

FIGURE 7.

${ }^{1} \mathrm{H}-{ }^{19} \mathrm{~F}$ HOESY spectra of 9-F-B $g \mathrm{Ch}(\mathbf{8}$, left $)$ and of 5-F-Ch $(\mathbf{4}$, right $)$. 


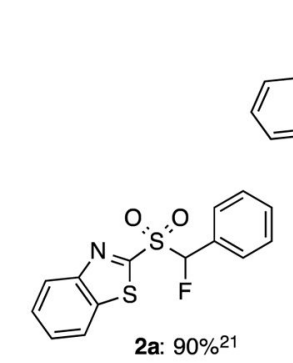

${ }^{19} \mathrm{~F}\left(282 \mathrm{MHz}, \mathrm{CDCl}_{3}\right)$ :

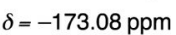
(d, ${ }^{2} J_{\mathrm{FH}}=45.8 \mathrm{~Hz}$ )
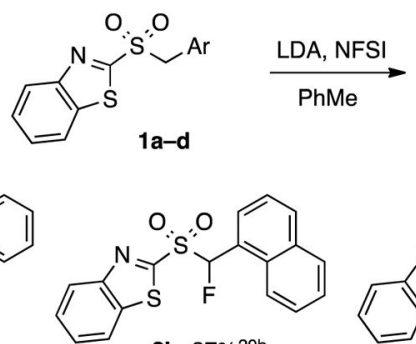

2b: $87 \%{ }^{20 b}$

$$
\delta=-172.19 \mathrm{ppm}
$$

(d, ${ }^{2} J_{\mathrm{FH}}=50.3 \mathrm{~Hz}$ )

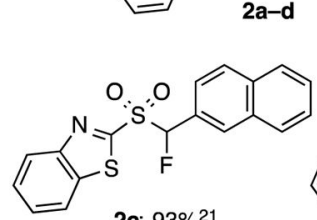

2c: $93 \% 21$

$\delta=-171.59 \mathrm{ppm}$

(d, ${ }^{2} J_{\mathrm{FH}}=45.7 \mathrm{~Hz}$ )

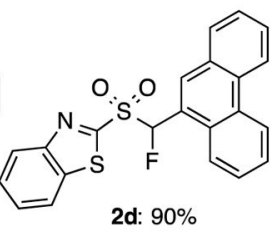

$\delta=-172.52 \mathrm{ppm}$

(d, ${ }^{2} J_{\mathrm{FH}}=45.8 \mathrm{~Hz}$ )

SCHEME 1.

Synthesis of (Aryl)fluoromethyl BT Sulfones 2a-d 


\section{TABLE 1}

Synthesis of Fluoroalkenes and the Regiospecifically Fluorinated PAHs

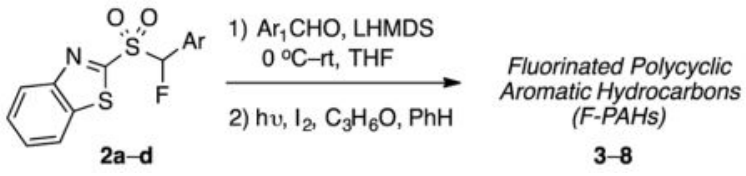

entry sulfone; $\mathrm{Ar}_{1} \mathrm{CHO}: \mathrm{Ar}_{1}=$ fluoroalkene intermediate: yield, ${ }^{a} E: Z$ ratio; ${ }^{b}{ }^{19} \mathrm{~F}$

F-PAHs 3-8: yield; ${ }^{a 19} \mathrm{~F}$ NMR data $c$ NMR data $c$

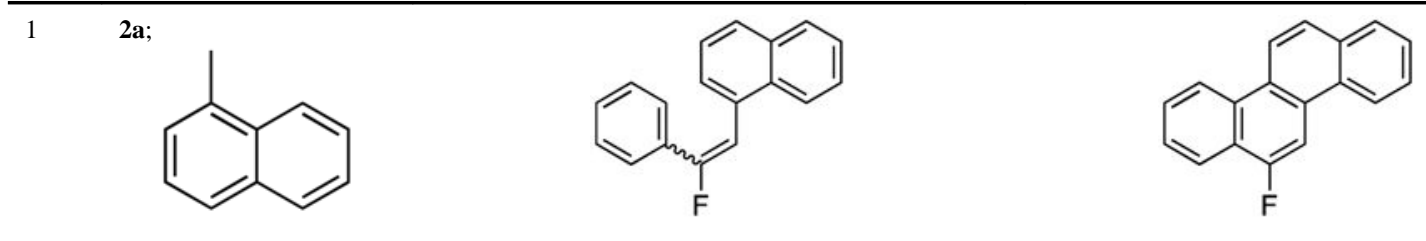

$99 \%, 2.8: 1 ; \delta-100.0 \mathrm{ppm}\left(\mathrm{d},{ }^{3} J_{\mathrm{FH}}=21.4 \mathrm{~Hz}, E-\right.$ isomer); $-115.6 \mathrm{ppm}\left(\mathrm{d},{ }^{3} J_{\mathrm{FH}}=39.7 \mathrm{~Hz}, Z\right.$-isomer $)$

2

$\mathbf{2 b}$;<smiles>Cc1ccccc1</smiles>

3

$2 a$<smiles>Cc1ccc2ccccc2c1</smiles>

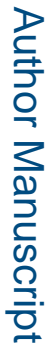

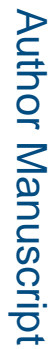

$2 \mathrm{c}$<smiles>Cc1ccccc1</smiles>

2a<smiles>F/C(=C/c1ccccc1)c1cccc2ccccc12</smiles>

$81 \%, 2.9: 1 ; \delta-84.4 \mathrm{ppm}\left(\mathrm{d},{ }^{3} J_{\mathrm{FH}}=18.3 \mathrm{~Hz}, E-\right.$ isomer); $-95.2 \mathrm{ppm}\left(\mathrm{d},{ }^{3} J_{\mathrm{FH}}=39.7 \mathrm{~Hz}, Z\right.$-isomer $)$<smiles>FC(=Cc1ccc2ccccc2c1)c1ccccc1</smiles>

$99 \%, 2.9: 1 ; \delta-96.2 \mathrm{ppm}\left(\mathrm{d},{ }^{3} J_{\mathrm{FH}}=18.3 \mathrm{~Hz}, E-\right.$ isomer); $-114.4 \mathrm{ppm}\left(\mathrm{d},{ }^{3} J_{\mathrm{FH}}=39.7 \mathrm{~Hz}, Z\right.$-isomer $)$<smiles>Cc1cc2ccccc2c2ccccc12</smiles><smiles>F/C(=C/c1ccccc1)c1ccc2ccccc2c1</smiles>

$76 \%, 2.75: 1 ; \delta-96.6 \mathrm{ppm}\left(\mathrm{d},{ }^{3} J_{\mathrm{FH}}=21.4 \mathrm{~Hz}, E-\right.$ isomer); $-114.9 \mathrm{ppm}\left(\mathrm{d},{ }^{3} J_{\mathrm{FH}}=39.7 \mathrm{~Hz}, Z\right.$-isomer $)$<smiles>FC(=Cc1cc2ccccc2c2ccccc12)c1ccccc1</smiles>

$70 \%, 3.1: 1 ; \delta-100.3 \mathrm{ppm}\left(\mathrm{d},{ }^{3} J_{\mathrm{FH}}=21.4 \mathrm{~Hz}, E-\right.$ isomer); $-115.2 \mathrm{ppm}\left(\mathrm{d},{ }^{3} J_{\mathrm{FH}}=36.6 \mathrm{~Hz}, Z\right.$-isomer $)$
3: $72 \% ; \delta-123.8 \mathrm{ppm}(\mathrm{d}, J=15.3 \mathrm{~Hz})$<smiles>Fc1cc2ccccc2c2ccc3ccccc3c12</smiles>

4: $71 \% ; \delta-111.8$ ppm (br dt, ${ }^{d} J=15.7,3.3$ $\mathrm{Hz})$<smiles>Fc1cc2ccc3ccccc3c2c2ccccc12</smiles>

5: $66 \% ; \delta-125.4 \mathrm{ppm}(\mathrm{d}, J=9.2 \mathrm{~Hz})$<smiles>Fc1cc2ccccc2c2c1ccc1ccccc12</smiles>

6: $83 \% ; \delta-125.8 \mathrm{ppm}(\mathrm{d}, J=12.2 \mathrm{~Hz})$<smiles>Fc1cc2c3ccccc3c3ccccc3c2c2ccccc12</smiles>

7: $77 \% ; \delta-124.3 \mathrm{ppm}(\mathrm{d}, J=12.2 \mathrm{~Hz})$ 


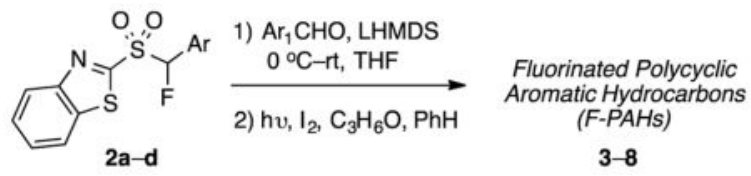

\section{entry sulfone; $\mathrm{Ar}_{1} \mathrm{CHO}: \mathrm{Ar}_{1}=\quad$ fluoroalkene intermediate: yield, ${ }^{a} E: Z$ ratio; ${ }^{b}{ }^{19} \mathrm{~F} \quad$ F-PAHs 3-8: yield; ${ }^{a}{ }^{19} \mathrm{~F}$ NMR data ${ }^{c}$} NMR data ${ }^{c}$

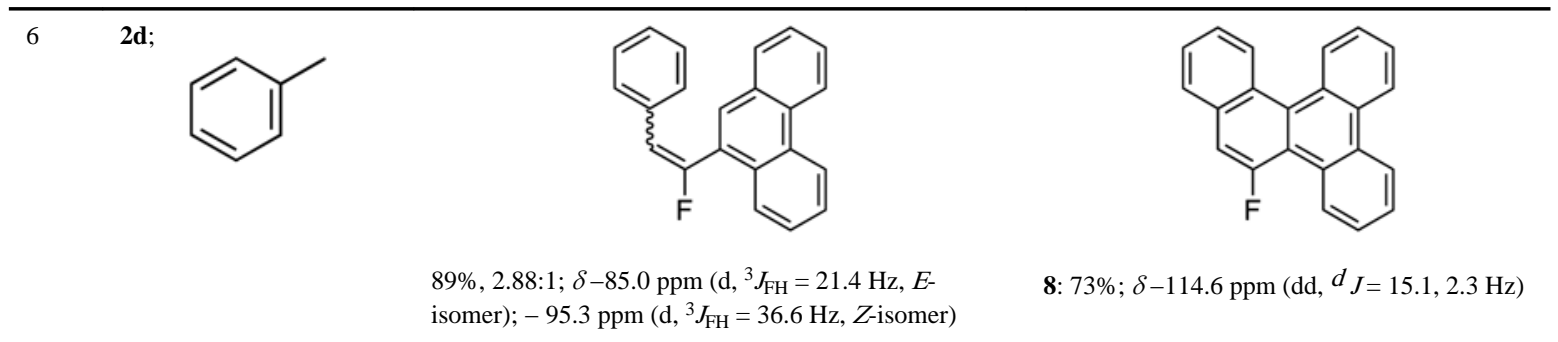

\footnotetext{
${ }^{a}$ Yields are of isolated and purified products.

${ }^{b} E / Z$ olefin ratios in the crude reaction mixtures were determined by ${ }^{19} \mathrm{~F}$ NMR prior to isolation.

$c^{c}$ Obtained at $282 \mathrm{MHz}$ in $\mathrm{CDCl}_{3}$, with $\mathrm{CFCl}_{3}$ as an internal reference.

${ }^{d}$ Obtained with resolution enhancement.
} 
TABLE 2

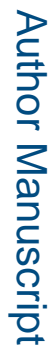

Angles between the Four Planes of Ch, 6-F-Ch, and 5-F-Ch ${ }^{a}$

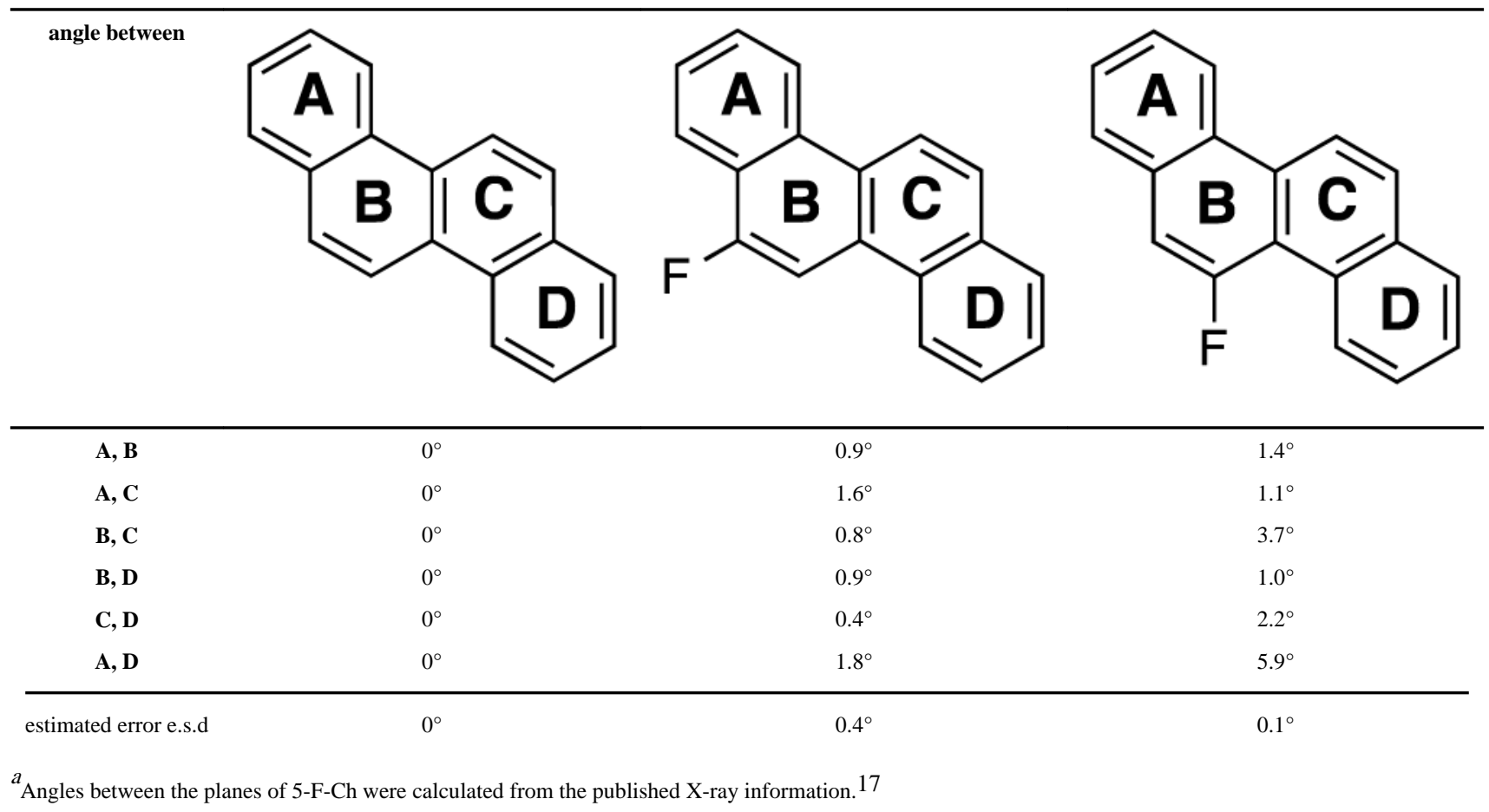

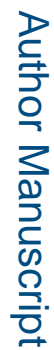

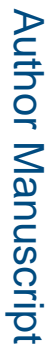

A,

A

A

Y

D

$\mathrm{F}$

D 
TABLE 3

Angles between the Four Planes of Unfluorinated and Fluorinated BcPh

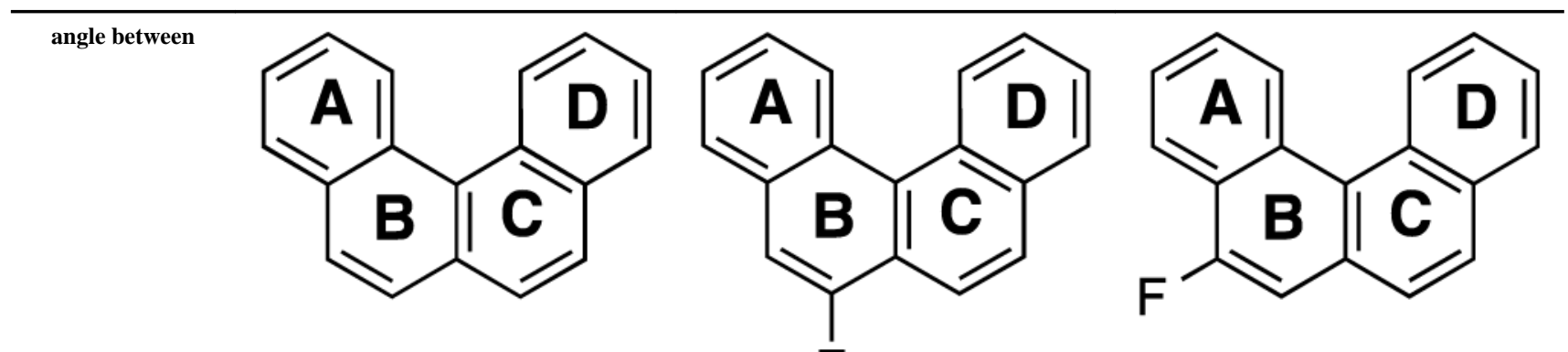

$\mathrm{F}$

\begin{tabular}{cccc}
\hline $\mathbf{A}, \mathbf{B}$ & $10.3^{\circ}$ & $9.4^{\circ}$ & $8.2^{\circ}$ \\
$\mathbf{A}, \mathbf{C}$ & $18.1^{\circ}$ & $16.2^{\circ}$ & $14.2^{\circ}$ \\
$\mathbf{B}, \mathbf{C}$ & $7.9^{\circ}$ & $6.8^{\circ}$ & $7.1^{\circ}$ \\
$\mathbf{B}, \mathbf{D}$ & $16.6^{\circ}$ & $15.2^{\circ}$ & $17.0^{\circ}$ \\
$\mathbf{C}, \mathbf{D}$ & $8.8^{\circ}$ & $8.8^{\circ}$ & $9.9^{\circ}$ \\
$\mathbf{A}, \mathbf{D}$ & $26.7^{\circ}$ & $24.3^{\circ}$ & $23.6^{\circ}$ \\
\hline estimated error e.s.d & $0.1^{\circ}$ & $0.2^{\circ}$ & $0.2^{\circ}$
\end{tabular}


TABLE 4

Angles between the Five Planes of Unfluorinated and Fluorinated $\mathrm{B} g \mathrm{Ch}$

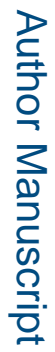

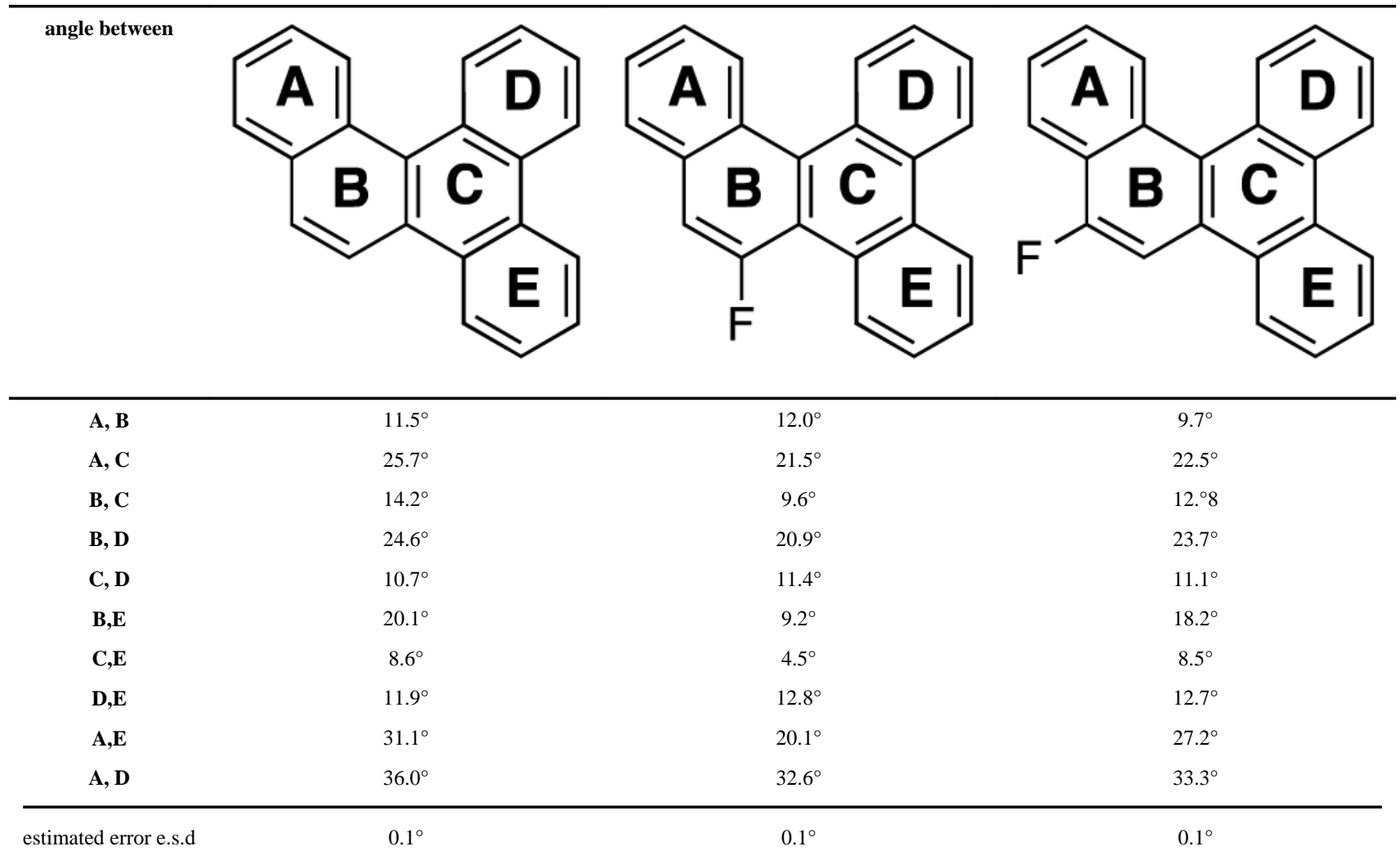

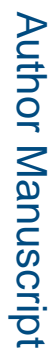

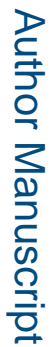

$\mathrm{A}, \mathrm{C}$

$25.7^{\circ}$

$21.5^{\circ}$

B, D

$24.6^{\circ}$

$20.9^{\circ}$

$\mathrm{C}, \mathrm{D}$

estimated error e.s.d

0.1 